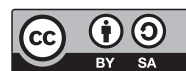

DOI 10.31261/IR.2020.04.11

\title{
Litteraria
}

\section{Siergiej Lozow}

Siergiej Władimirowicz Lozow — lingwista, badacz Nowego Testamentu — urodził się 9 maja 1954 roku w Smoleńsku'. Jego życiorys mógłby posłużyć za temat do powieści o niespokojnym umyśle, który po latach różnych przygód odnalazł spokój w studiowaniu martwych lub umierających języków. Urodzony w rodzinie lekarskiej, wychowany został przez dziadków. Od dziecka chciał być lingwistą, ale powodowany miłością do dziewczyny, zaczął studia medyczne. Przerwał je, został powołany na trzy lata do wojska. Wspominał ten okres następująco: „Dużo czytałem po angielsku, ze słownikiem Millera, w tym gramatykę, nadto prace z zakresu lingwistyki rosyjskiej, np. Morfologię Winogradowa"2. W 1981 roku ukończył studia filologiczne (w zakresie filologii romańskiej) na Uniwersytecie Moskiewskim im. M.W. Łomonosowa (MGU) na podstawie pracy Podmiotowa struktura powieści Dostojewskiego „Bracia Karamazow" i jej przekaz w dwóch włoskich przekładach (Субъектная структура романа Достоевского "Братья Карамазовы" и ее передача в двух итальянских переводах), napisanej pod kierunkiem prof. Tatiany Alisowej (1924-2014), jednej z najwybitniejszych italianistek rosyjskich, od 1974 roku członka-korespondenta włoskiej Accademia della Crusca.

W czasie studiów Lozow zetknął się z kulturą niezależną, nową myślą teologiczną, filozoficzną i polityczną. Lektura Archipelagu GUŁag Aleksandra Sołżenicyna i Dennych wyżyn Aleksandra Zinowjewa wymusiła na nim inne spojrzenie na rzeczywistość ZSRR.

\footnotetext{
Informacje biograficzne na podstawie rozmów Aleksieja Ogniowa z Siergiejem Lozowem: Если всё было фигней - мы стали ближе к истине, «Троицкий вариант - Наука» 2017, nr 225, s. 8-9, https://trv-science.ru/2017/03/29/lyozov/ [08.12.2019]; Мы отвечаем за арамейский язык перед небытием, «Троицкий вариант - Наука» 2017, nr 228, s. 8-9 (online: https://trv-science.ru/2017/05/08/lyozov-2/ [08.12.2019].

2 Если всёбыло фигней — мы стали ближе к истине... (tłum. moje - M. K.).
} 
Powiedział później, „że człowiek kształtuje swoje życie jako reakcję na nadchodzące wyzwania intelektualne, to znaczy: zmienia swoje życie w odpowiedzi na te wyzwania"3. Po przeczytaniu Głównych nurtów marksizmu Leszka Kołakowskiego krytycznie odniósł się do prac grupy "Młodych socjalistów" (grupa Pawła Kudiukina, Borisa Kagarlickiego i Andrieja Fadina), mieszczących się w obrębie idei zarówno lewicowego eurokomunizmu, jak też prawicowej socjaldemokracji. W tym czasie zbliżył się do chrześcijaństwa, ponieważ wydało się mu to odpowiednie do zamanifestowania indywidualnego oporu wobec władzy. Znalazł się w kręgu Aleksandra Mienia (1935-1990), ekumenicznego filozofa religijnego i teologa prawosławnego, któremu później zarzucił brak zdecydowanej postawy w zwalczaniu "kolaboracjonizmu wewnątrz prawosławia"4. Zaangażował się też w ruch obrony praw człowieka, został członkiem moskiewskiego Komitetu Helsińskiego (1989-1990), wchodził w skład redakcji czasopism „Ekspress-Chroniki” oraz "Strana i Mir". Od połowy lat 90. XX wieku deklaruje światopogląd liberalny i wykazuje dystans wobec dzisiejszego rosyjskiego establishmentu.

Po studiach Lozow pracował jako nauczyciel języków hiszpańskiego i włoskiego w szkole wieczorowej, w 1983 roku został zatrudniony w Instytucie Informacji Naukowej Nauk Społecznych ówczesnej Akademii Nauk. Tutaj, obok redakcji językowej, zajmował się studiowaniem Nowego Testamentu. Wraz z Walentyną Kuzniecową (tłumaczką) oraz Siergiejem Tiszczenką (kulturoznawcą) przygotował komentowane wydanie czterech ewangelii kanonicznych ${ }^{5}$. W tym czasie tłumaczył i/lub redagował pisma Martina Bubera, Paula Tillicha, Hansa Kelsena oraz przygotował - wraz z Olgą Worową - wybór najważniejszych dwudziestowiecznych prac teologicznych (m.in. Karla Bartha, Dietricha Boenhoffera, Emila L. Fackenheima, Rudolfa Bultmanna) ${ }^{6}$. Rozprawę doktorską pt. Historia i hermeneutyka w nauczaniu Nowego Testamentu (История и герменевтика в изучении Нового Завета) obronił w roku 1994 w Rosyjskim Państwowym Uniwersytecie Humanistycznym (RGGU), z którym jest związany zawodowo od roku 1992. Rozprawa ukazała się jako osobna książka, została też

Tamże.

4 С. Лёзов, Религиозное возрождение или капитуляция?, «Страна и мир» [Мюнхен] 1986, nr 12, s. 28-36.

5 С.В. Лёзова, С.В. Тищенко (red.), Канонические евангелия, przeł. z greckiego В.Н. Кузнецова, Наука, Восточная литература, Москва 1992.

6 М. Бубер, Два образа веры, Республика, Москва 1995; П. Тиллих, Избранное. Теология культуры. Юрист, Москва 1995; Г. Кельзен, Чистое учение о праве, przeł. М.В. Антонов, С.В. Лёзов, АлефПресс, Санкт-Петербург 2015; Социально-политическое измерение христианства. Избранные теологические тексты ХХ века, Восточная литература, Москва 1994. 
włączona do autorskiego tomu pism wybranych Loozowa Próba zrozumienia 7 .

Poliglota - znawca licznych języków nowożytnych: m.in. angielskiego, francuskiego, hiszpańskiego, niemieckiego, włoskiego - na przełomie stuleci odszedł od aktywnego udziału w życiu społecznym i poświęcił się studiom nad Nowym Testamentem (przełożył ze starogreckiego Ewangelię św. Marka), a także badaniom nad morfologią i syntaktyką wyrazu oraz gramatyką historyczną języków semickich (m.in. akadyjskiego, aramejskiego, hebrajskiego, turoyo). Wypowiedział słynne zdanie: „Jesteśmy odpowiedzialni za aramejski przed niebytem" ${ }^{8}$. Jego liczne prace językoznawcze publikowane są na łamach prestiżowych czasopism ${ }^{9}$.

Esej Siergieja Lozowa, który tutaj przedstawiamy, powstał w latach 1988-1990, był publikowany wielokrotnie w różnych wersjach. Najpierw jako Chrześcijaństwo po Auschwitz, później jako Idea narodowa a chrześcijaństwo ${ }^{10}$. Wersja pełna eseju została przedrukowana w antologii Zoi Krachmalnikowej Rosyjska idea a Żydzi, a także w autorskim tomie prac wybranych Próba zrozumienia ${ }^{11}$. Skrót części drugiej eseju - Rosyjskie prawosławie i nowy patriotyzm - ukazał się w przekładzie na język angielski, całość eseju natomiast po niemiecku². Po polsku praca ta ukazuje się po raz pierwszy. Podstawą przekładu jest — zaaprobowana przez autora - ostateczna wersja jego eseju z tomu Próba zrozumienia, porównana z maszynopisem, zamieszczonym na stronie internetowej RGGU (w autorskim wykazie publikacji za rok 1990) ${ }^{13}$.

Esej składa się z dwóch autonomicznych, lecz mocno ze sobą związanych części. W pierwszej z nich autor zadaje pytanie o polityczną i moralną odpowiedzialność chrześcijaństwa za antysemityzm i Holokaust. Nawiązując do protestanckiej „teologii po Auschwitz", zastanawia się nad odpowiedzialnością Kościoła (Cerkwi)

С. Лёзов, История и герменевтика в изучении Нового Завета, Восточная литература, Москва 1996, 375 s.; tenże, Попытка понимания. Избранные работы, Университетская книга, Москва-СанктПетербург 1999, s. 355-563.

8 „Мы отвечаем за арамейский язык перед небытием". . .

9 Zob. spis publikacji Lozowa na jego stronie internetowej: http://ivka.rsuh.ru/article.html?id=78809 lub https://www.hse.ru/staff/sloesov\#sci [08.12.2019].

10 С. Лёзов, Христианство после Освенцима, «Страна и мир» [Мюнхен] 1990, nr 1, s. 128-134; tenże, Нaциональная идея и христианство, «0ктябрь» 1990, nr 10, s. 148-160.

11 М. Крахмальникова (red.), Русская идея и евреи. Роковой спор. Христианство, антисемитизм, национализм, Наука, Восточная литература, Москва 1994; С. Лёзов, Попытка понимания. .., s. 231-254.

12 S. Loesov, Russian Orthodoxy and the New Patriotism, "Holocaust and Genocide Studies" 1991, vol. 6, issue 3, s. 253-267; S. Lösov, Nationale Idee und Christentum, w: Die Fesseln der Vergangenheit. Russisches Denken nach der Perestroika, hrsg. S. Margolina, Fischer Taschenbuch, Frankfurt a. M. 1993, s. 65-99.

13 Zob. http://ivka.rsuh.ru/article.html?id=78809 [08.12.2019]. 
za Holokaust, nad wielowiekowym antyjudaizmem kościelnym jako jednym ze źródeł antysemityzmu rasistowskiego oraz nad możliwościami przekształcenia najgłębszych podstaw nauczania chrześcijańskiego w kontekście doświadczenia Holokaustu. W części drugiej - pyta o związek prawosławia z tzw. „nowym patriotyzmem" Frontu Narodowo-Patriotycznego "Pamięć", który ujawnił się w postawach agresywnego antysemityzmu rasistowskiego.

Po publikacji eseju, Lozowowi zarzucono myślenie publicystyczne i wyjaskrawienie stanowisk. W ostatniej dekadzie XX wieku okazało się, że niemieckie i amerykańskie idee "teologii po Auschwitz" nie dały się przeszczepić na grunt rosyjski. W czasie postkomunistycznego odradzania się prawosławia zostały odrzucone jako ideowo obce ${ }^{14}$. Lozow uznał to za wielki błąd, a przynajmniej za utraconą szansę na intelektualne porozumienie chrześcijaństwa i judaizmu. Napisał w poincie swojego eseju O niepowstaniu chrześcijaństwa z judaizmu:

„Teologia dialogu w ostatnich dziesięcioleciach zastąpiła teologię misji. Jest to funkcjonalna zamiana: w obu przypadkach odczuwamy potrzebę pogłębionego zrozumienia judaizmu w takim sensie, w jakim nie musimy rozumieć islamu. Liberalni chrześcijanie w kontekście tego dialogu wykształcili coś, co przypomina kompleks niższości. Szczególnie interesujące są przypadki przejścia aktywnych chrześcijan (w szczególności teologów chrześcijańskich!) na judaizm; czasem towarzyszy temu emigracja do Izraela. Oczywiście, takie duchowe przygody opierają się na założeniu, że istnieje tylko jedna prawda (lub w tym przypadku: jest tylko jedna prawda). Okazuje się, że poszukiwacze prawdy rozumują lub czują tak: jeśli judaizm nie jest niedokończonym chrześcijaństwem, to chrześcijaństwo okazuje się zepsute przez judaizm, a zatem nie jest prawdą. Ale jeśli pytanie o prawdę w ogóle nie jest przemyślane, to i ,wspólne korzenie' mogą nie być rozumiane tak, jak są one rozumiane, dlatego chrześcijański dialog z Żydami, a raczej chrześcijański monolog o Żydach i w obecności Żydów (jak to jest praktykowane na Zachodzie i jak powoli pojawia się i u nas) traci swój niewyjaśniony i ekscytujący urok"15.

Marian Kisiel

14 В. Лихачев, Политический антисемитизм в современной России (сz. 3: Религия, rozdz. 1: Антисемитизм, православная церковь и государство в современной России, https://www.sova-center.ru/ racism-xenophobia/publications/antisemitism/political-antisemitism/2003/08/d763/ [08.12.2019].

15 С. Лёзов, О непроисхождении христианства из иудаизма, w: tegoż, Попытка понимания. .., s. 19-20. 


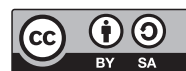

DOI 10.31261/IR.2020.04.12

SIERGIEJ LOZOW

Idea narodowa a chrześcijaństwo

Esej w dwóch częściach

\section{Chrześcijaństwo po Auschwitz}

Dzisiejszy kult agresywnego nacjonalizmu i antysemityzmu w społeczeństwie rosyjskim, prowadzący do wyrzucenia Żydów z Rosji i skutkujący wieloma poważnymi następstwami w przyszłości, rozpatrywany jest najczęściej w kontekście czysto politycznym. Jeśli chodzi o wymiar historyczny, to nasza własna historia jest zasadniczo tym, co mamy na podorędziu: jest to rosyjska myśl narodowa XIX-XX wieku, rosyjska państwowość imperialna ostatnich trzech stuleci, dziesięć wieków rosyjskiego chrześcijaństwa itp. Zawsze zajmowała nas problematyka historiozoficzna i w tej dziedzinie napisano tyle, że autor próbujący przy analizie antysemityzmu oprzeć się na jakimś rozumieniu rosyjskiej historii, znajduje się dzisiaj jakby na wiecu, gdzie każdy stara się przekrzyczeć wszystkich i nikt nikogo nie słucha. Przecież każdy ma własne zdanie na temat Żydów, równego Apostołom księcia Włodzimierza, przyczyn rosyjskiej rewolucji, schizmy w Cerkwi w XVII wieku, rosyjskiej idei, Dostojewskiego, Lenina, źródeł i znaczenia rosyjskiego komunizmu, prawdziwej istoty prawosławia i wielu innych rzeczy.

Wydaje mi się, że w debacie o rosyjskim nacjonalizmie XX wieku, w szczególności zaś o miejscu prawosławia i antysemityzmu we w nątrz tego fenomenu, pomocny mógłby być punkt widzenia sytuujący się poza płaszczyzną zwykłych politycznych i historiozoficznych dyskusji. Chcę przedstawić taki punkt widzenia w nadziei, 
że okaże się on czytelnikowi pomocny w jego rozmyślaniach na te tematy.

Zapewne wielu zgodzi się z tym, że jednym z głównych wynalazków XX wieku są obozy masowej zagłady, że wejdzie on do historii jako wiek Gułagu i Auschwitz. Mnie, chrześcijanina i historyka myśli chrześcijańskiej doby najnowszej, zawodowo interesują istniejące próby t e olog i c z n e g o zrozumienia tego prawdziwie nowego zjawiska. Tym samym, czytelnik ma prawo oczekiwać opowieści o przemyśleniach prawosławnej teologii na temat Gułagu i wszystkiego, co kryje się pod tym słowem, ma prawo oczekiwać refleksji na temat: "rosyjska teologia po Gułagu”. Ale nie ma prawosławnego przemyślenia Gułagu. Nie ma p r a w o sła w n e j t e olog i p o Guła gu, po prostu dlatego, że nie ma również w języku rosyjskim teologii chrześcijańskiej.

Pozostaje Auschwitz. Chcę pokazać, że niektóre istotne odkrycia myśli zachodniochrześcijańskiej mogą okazać się ważne również dla nas.

W zachodniej (przede wszystkim w amerykańskiej i niemieckiej) literaturze teologicznej Auschwitz jest jednym z symboli eksterminacji Żydów europejskich w czasie panowania narodowego socjalizmu. Żydzi nazywają to zdarzenie Katastrofą albo słowem Szoa, tzn. „nieszczęście”, „zagłada”. Ale najczęściej używane jest słowo Holokaust, co po grecku znaczy: „ofiara całopalna”. Słowo to pochodzi ze starogreckiego przekładu Biblii żydowskiej i oznacza taki obrzęd ofiarny, w czasie którego ciało zwierzęcia ofiarnego całkowicie zostaje spalone.

Znaczenie biblijnej metafory jest jasne. Pisarz Jean Améry ${ }^{1}$, uratowany z obozu zagłady i później przez całe życie próbujący sobie poradzić z „przymusem i niemożnością bycia Żydem” (walka ta skończyła się samobójstwem 17 października 1978 roku), tak o tym powiedział: „Wszyscy a r yjs c y więźniowie, chociaż byli z nami w tej samej otchłani, stali wyżej, a ponadto byli oddaleni od nas o kilku lat świetlnych. Żyd był z wierzęciem ofiar-

Jean Améry (właśc. Hans Mayer, 1912-1978), pisarz żydowski urodzony w Wiedniu. Po Anschlussie Austrii wyemigrował do Belgii. Działał w ruchu oporu, był więźniem Auschwitz, Buchenwaldu, Bergen-Belsen. Po wojnie korespondent kulturalny prasy szwajcarskiej. Polskie wydania jego prac: o starzeniu się. Bunt i rezygnacja; Podnieść na siebie rękę. Dyskurs o dobrowolnej śmierci, przeł. B. Baran, Czytelnik, Warszawa 2007; Poza winq i karq. Próby przełamania podjęte przez złamanego, przeł. R. Turczyn, posłowie P. Weiser, Wydawnictwo Homini, Kraków 2007; Podnieśćna siebie rękę. Dyskurs o dobrowolnejśmierci, przeł. B. Baran, Wydawnictwo Aletheia, Warszawa 2018 [przyp. tłum.]. 
ny m... Musiał wypić kielich do ostatniej, najbardziej gorzkiej kropli. Wypiłem ją. Wtedy właśnie do mnie dotarło, co znaczy być Żydem"2.

Czym jest „chrześcijaństwo po Auschwitz"? Jakie znaczenie ma problem Auschwitz we współczesnej teologii chrześcijańskiej? Pierwsze podejście do tego zagadnienia można sformułować tak: "Żydów eksterminowali nie chrześcijanie, ale naziści i ich pomocnicy (choć w większości byli oni ochrzczeni i wychowywali się w środowisku chrześcijańskim, a niektórzy uważali się za członków Kościoła). Ale odpowiedzialność za to, że było to możliwe, spoczywa również na chrześcijanach".

Jaka jest to odpowiedzialność? W 1946 roku znany niemiecki filozof Karl Jaspers opublikował książkę Problem winy, w której była mowa o „niemieckiej winie”, to jest o winie narodu niemieckiego za zbrodnie przeciwko ludzkości dokonane przez narodowych socjalistów. Książka ta stała się znaczącym zjawiskiem w życiu duchowym powojennych Niemiec ${ }^{3}$. Podobnego postawienia problemu oczekujemy również w debacie na temat "chrześcijaństwa po Auschwitz". W istocie rzeczy jednak mowa tu nie o „niemieckiej winie”, ale o czymś o wiele bardziej fundamentalnym. We współczesnej chrześcijańskiej (nie tylko niemieckiej) teologii głównie omawia się nie moralno-polityczną odpowiedzialność chrześcijan za Holokaust, ale kwestię istoty „bycia chrześcijaninem” po Katastrofie, kwestię najgłębszego jądra chrześcijaństwa w obliczu Holokaustu.

Filozof i teolog Paul Tillich, jeden z najwybitniejszych twórców myśli chrześcijańskiej naszego wieku ${ }^{4}$, powiedział, że chrześcijanin dzisiaj „nie może przyłączyć się do chóru tych, którzy żyją w 'świecie niepodważalnych twierdzeń'"'5. Tillich miał na uwadze nie Katastrofę, ale współczesny kryzys zaufania do wszystkich istniejących

2 Cyt. za J.B. Metz, Jenseits bürgerlicher Religion. Reden über die Zukunft des Christentums. Kaiser, München - Grünewald, Mainz 1980, s. 35. [Johann Baptist Metz (1928-2019), teolog niemiecki, uczeń i przyjaciel Karla Rahnera, jeden z najbardziej wpływowych przedstawicieli tzw. „nowej” teologii politycznej. Wniósł wielki wkład do "teologii po Auschwitz” (jak mówić o Bogu i jak rozwijać teologię). Z ważniejszych jego prac: Teologia polityczna, przeł. A. Mosurek, Wydawnictwo WAM, Kraków 2000; Teologia wobec cierpienia, przeł. J. Zychowicz, Wydawnictwo WAM, Kraków 2008 [przyp. tłum.].

3 Zob. K. Jaspers, Problem winy. 0 politycznej odpowiedzialności Niemiec, przeł. J. Garewicz, Narodowe Centrum Kultury, Warszawa 2018. [Karl Jaspers (1883-1960), jeden z najwybitniejszych filozofów niemieckich, przedstawiciel egzystencjalizmu]. [przyp. tłum.]

4 Paul Tillich (1886-1965), niemiecki filozof i teolog, od 1933 roku w USA, wykładowca Union Theological College w Nowym Jorku, jeden z najznakomitszych teologów protestanckich XX wieku. Główne dzieła: Dynamika wiary, przeł. A. Szostkiewicz, W drodze, Poznań 1987; Męstwo bycia, przeł. H. Bednarek, Rebis, Poznań 1994; Pytanie o Nieuwarunkowane, przeł. J.Zychowicz, Znak, Kraków 1996; Teologia systematyczna, t. 1-3, przeł. J. Marzęcki, Antyk, Kęty 2004-2005. [przyp. tłum.]

5 P. Tillich, Teologia systematyczna, t. 1, s. 31 (pol. tłum.: „W sferze niezłomnych twierdzeń”). 
systemów światopoglądowych, w tym również do chrześcijaństwa. Słowami Tillicha da się wszakże wyrazić wyjściową tezę t e o l o g i i po A u s chwit z: dzisiaj, po Katastrofie, chrześcijanin nie może dłużej żyć w „świecie niepodważalnych twierdzeń".

Dlaczego eksterminacja Żydów wywołała u chrześcijan kryzys zaufania do istoty własnej wiary? Szczegółowo będzie o tym mowa dalej. Wpierw zaznaczę jednak, że zachodnie chrześcijaństwo byłoby dzisiaj martwą ideologią, gdyby ten kryzys, nawet z dużym opóźnieniem, jeszcze się nie zaczął. Pierwsze próby chrześcijańskiego zrozumienia Holokaustu pojawiają się pod koniec lat sześćdziesiątych XX wieku. Omawiamy więc kierunek myśli chrześcijańskiej, która zaczyna rozwijać się na naszych oczach. Już w roku 1968 żydowski filozof Emil Fackenheim miał prawo powiedzieć: „Świat nieżydowski uchyla się przed Auschwitz z powodu jego potworności, ale także z powodu rzeczywistego lub wyobrażonego udziału w winie za Auschwitz"'.

Z historycznego punktu widzenia wydzieliłbym tu trzy etapy zgłębienia tej problematyki.

1. Uznanie moralno-politycznej odpowiedzialności Kościoła za Katastrofę. Chodzi o to, że już po dojściu Hitlera do władzy Kościoły — protestancki i katolicki, europejskie i amerykańskie — mogły wystąpić w obronie Żydów, lecz tego nie uczyniły. Takie uznanie szczególnej odpowiedzialności zawarto, na przykład, w rezolucji O odnowieniu kontaktów między chrześcijanami i Żydami, przyjętej przez synod niemieckich protestantów w Nadrenii w 1980 roku? Zaznaczmy, że podobnego uznania brakuje w Nostra aetate, fundamentalnym dokumencie Soboru Watykańskiego II o relacjach Kościoła Katolickiego do Żydów.

2. Chrześcijańscy teologowie zaczęli badać wielowiekowy a n tyjudaizm kościelny jako jedno ze źródeł współczesnego antysemityzmu rasistowskiego. Długa historia kościelnej wrogości do Żydów zaczęła teraz przybierać nowy, złowieszczy sens. Na przykład, reguła IV Soboru Laterańskiego (1215), odnosząca się do porządku, jaki powinien zostać stworzo-

6 E. L. Fackenheim, Żydowska wiara a Holocaust. Fragment, przeł. A. Musiał, w: P. Śpiewak (red.), Teologia i filozofia żydowska wobec Holokaustu, słowo/obraz terytoria, Gdańsk 2013, s. 347. [Emil Ludwig Fackenheim (1916-2003), filozof, teolog i rabin judaizmu reformowanego, znawca myśli Kanta, Hegla i Schellinga, syjonista. Jeden z najważniejszych przedstawicieli „filozofii po Auschwitz". Z ważniejszych opracowań: P. Weiser, Auschwitz i Jerozolima. Pojęcie Holokaustu według Emila Fackenheima, Wydawnictwo Uniwersytetu Jagiellońskiego, Kraków 2010; K. Kornacka-Sareło, „Religia kosmicznego uniesienia". Kabalistyczne źródła żydowskiej teodycei „po Auschwitz”, „Studia Religiologica” 2015, nr 1 (48), s. 26-28].

7 Zur Erneuerung des Verhältnisses von Christen und Juden. „Die Erklärung der Landessynode der Evangelischen Kirche im Rheinland" 1980. 
ny dla Żydów wewnątrz wspólnoty chrześcijańskiej, okazała się zbieżna z nazistowskim prawodawstwem rasowym. Sobór postanowił, że Żydzi powinni nosić na ubraniu odróżniające ich znaki, jak trędowaci lub prostytutki. To antycypowało rozporządzenie z 1 września 1941 roku, zgodnie z którym Żydzi na terytorium kontrolowanym przez Rzeszę mieli przyszywać na ubraniach żółte sześcioramienne gwiazdy.

Chrześcijanie zaczęli dostrzegać głosy świadków, którzy przeżyli Holokaust. Tutaj należy wspomnieć choćby Elie Wiesela ${ }^{8}$, który jako nastolatek znalazł się w Auschwitz. Elie Wiesel został światowej sławy pisarzem, laureatem Pokojowej Nagrody Nobla, „posłańcem ludzkości”, jak powiedział o nim znany chrześcijański teolog Robert McAfee Brown, autor książki o jego twórczości9

Dla chrześcijan, zaczynających rozumieć o czym jest mowa, ważne stały się także głosy żydowskich filozofów, teologów i historyków, piszących o Holokauście. Dlatego i my będziemy się w nie wsłuchiwać. Punkty wspólne między wczesnochrześcijańskim i średniowiecznym prawem kanonicznym, z jednej strony, a nazistowskim prawodawstwem, z drugiej, szczegółowo rozpatrzył historyk Katastrofy Raul Hilberg w swoim fundamentalnym dziele Zagłada Żydów europejskich. Zdaniem Hilberga, nazistowskie "ostateczne rozwiązanie kwestii żydowskiej"10 należy rozpatrywać w związku z chrześcijańskimi prześladowaniami Żydów. Hilberg wyodrębnia trzy rodzaje antyżydowskiej polityki, następujące jeden po drugim, poczynając od IV wieku n.e., to znaczy od chwili, kiedy chrześcijaństwo stało się religią państwową w Imperium Rzymskim: nawrócenie na chrześcijaństwo, wygnanie (w tym również wygnanie do getta) i zagłada. „Chrześcijańscy misjonarze — pisze Hilberg — w gruncie rzeczy mówili: nie macie prawa żyć wśród nas jako Żydzi. Po nich nadeszli władcy świeccy, twierdzący: nie macie prawa żyć wśród nas. Wreszcie niemieccy naziści zadeklarowali: nie macie prawa żyć.

Te coraz bardziej drastyczne cele powoli, lecz nieprzerwanie powodowały nasilenie działań antyżydowskich i wrogiego Żydom

8 Elie Wiesel (1928-2016), amerykański pisarz i dziennikarz żydowskiego pochodzenia, laureat Pokojowej Nagrody Nobla (1986), profesor Boston University. Więzień Auschwitz i Buchenwaldu. Po wojnie aktywny syjonista, inicjator budowy United States Holocaust Memorial Museum, pomysłodawca używania terminu Holocaust w zastosowaniu do ofiar nazizmu i komunizmu. W języku rosyjskim opublikowano przekład autobiograficznej trylogii Elie Wiesela Ночь. Рассвет. День, Олимп, Москва 1993. [przyp. tłum.]

9 R. McAfee Brown, Elie Wiesel. Messenger to all humanity, University of Notre Dame Press, London 1983. [Robert McAfee Brown (1920-2001), teolog amerykański, pisarz, kaznodzieja, zwolennik równych praw w kwestiach społecznych, ekonomicznych i płciowych. Był m.in. profesorem religii na Uniwersytecie Stanforda, a także protestanckim obserwatorem na Soborze Watykańskim II]. [przyp. tłum.]

10 Endlösung der Judenfrage - kryptonim niemieckiego programu zagłady Żydów europejskich. Zob. P. Szapiro, "ostateczne rozwiązanie", https://www.jhi.pl/psj/ostateczne_rozwiazanie [08.12.2019]. [przyp. tłum.] 
myślenia. Proces ten zapoczątkowała próba nawrócenia Żydów na chrześcijaństwo. Następną fazą było zmuszenie ofiar do opuszczenia kraju. Ostatnią fazą było zgładzenie Żydów. Niemieccy naziści nie odrzucali zatem przeszłości, ale budowali na niej. Nie rozpoczęli procesu, ale doprowadzili go do końca"11.

Wtedy też teologowie chrześcijańscy po raz pierwszy podjęli refleksję nad zagadnieniem „antyjudaizmu w Nowym Testamencie". Odkryli judofobiczny ${ }^{12}$ potencjał Nowego Testamentu, który w całości realizował się w historii Kościoła. Nieco dalej spróbuję objaśnić, na czym opierały się te niezwykłe dla rosyjskiej świadomości kulturowej idee.

3. Od Nowego Testamentu naturalne jest przejście do najgłębszej warstwy - do semantycznego jądra [смысловой центр] chrześcijaństwa, do chrystologii - chrześcijańskiej doktryny o Jezusie z Nazaretu jako Mesjaszu (Chrystusie) i Synu Bożym oraz do wynikających z niej uniwersalnych twierdzeń chrześcijaństwa. Stale ponawiana refleksja nad tymi nowymi zagadnieniami utwierdziła niektórych teologów w przekonaniu, że po Auschwitz również semantyczne jądro chrześcijańskiej teologii dogmatycznej powinno wyglądać inaczej.

Oczywiście, takie rozumienie wymaga uczciwości i gotowości do podjęcia bolesnych wysiłków w celu zrewidowania całej tradycji. Powiedziałbym, że dla konsekwentnego teologicznego przemyślenia Katastrofy przez chrześcijan potrzeba pewnej odwagi, by zadać pytanie o podstawy własnego światopoglądu.

Nieuchronność zwrotu w myśli chrześcijańskiej bardzo dokładnie wyraził w 1979 roku niemiecki teolog luterański Friedrich-Wilhelm Marquardt: „Dzisiaj Auschwitz zbliża się do nas jako sąd nad naszym chrześcijaństwem, nad minionym i obecnym obrazem naszego chrześcijańskiego bytu, i więcej nawet — jeżeli patrzeć oczami ofiar Auschwitz - zbliża się do nas jako sąd nad samym chrześcijaństwem”. I dalej: „Auschwitz zbliża się do nas jako wezwanie do pokuty i nawrócenia. Zmienić się powinno nie tylko nasze życie, ale i nasza wiara. Zrozumienie Auschwitz powinno skutkować nie tylko konsekwencjami etycznymi, ale także doktrynalnymi. Auschwitz wzywa nas do tego, abyśmy dzisiaj usłyszeli Słowo Boże inaczej niż je nam przekazali nasi nauczyciele teologii

11 R. Hilberg, Zagłada Żydów europejskich, t. 1, przeł. J. Giebułtowski, [wyd.] Piotr Stefaniuk, Warszawa 2014, s. 5. [Raul Hilberg (1926-2007), historyk amerykański żydowskiego pochodzenia, badacz Holokaustu. W innym dziele Hilberga Sprawcy, ofiary, świadkowie. Zagłada Żydów 1933-1945 (przeł. J. Giebułtowski, Centrum Badań nad Zagładą Żydów IFiS PAN, Wydawnictwo Cyklady, Warszawa 2007) wprowadzony został klasyczny trójpodział wyrażony w tytule (ang. Perpetrators - Victims - Bystanders)]. [przyp. łłum.]

12 Używam pojęć "judofobia" i „judofilstwo" (na oznaczenie antysemityzmu i filosemityzmu), zgodnie zzastosowaniem ich przez autora artykułu, choć w innych miejscach przywołuje on słowo „antysemityzm”. 
i kaznodzieje starszych pokoleń. Ten apel o pokutę i nawrócenie dotyka istoty chrześcijaństwa, inaczej niż ją dotąd pojmowaliśmy"13.

Żeby zrozumieć, dlaczego zachodni chrześcijanie sami uznali konieczność takich zmian, i żeby lepiej zobaczyć, co istotnie powinno się zmienić, proponuję wspólnie przeczytać tekst, który niedawno stał się szeroko dostępny i przez wielu, prawdopodobnie, zapamiętany: rozprawę Nikołaja Bierdiajewa Chrześcijaństwo i antysemityzm ${ }^{14}$. Należy pamiętać, że praca Bierdiajewa nie należy do jego mało znanych czy zapomnianych dzieł; przeciwnie, zawsze o niej wiedzieli specjaliści, przekładano ją na języki obce. Polityczna orientacja publikujących ją teraz "Drużby Narodow" i "Ogońka” pozwala sądzić, że pisma te postanowiły wykorzystać dzieło jednego z najbardziej znaczących rosyjskich filozofów jako „starej, lecz groźnej broni" w walce z narastającym antysemityzmem, którego kultywowanie stało się punktem wyjścia również w naszych rozważaniach.

Esej Bierdiajewa o religijnym losie Żydów - taki jest jego podtytuł - pozwoli nam zobaczyć "miniony obraz naszego chrześcijańskiego bytu"15, to znaczy niektóre ważne dla nas aspekty tej teologii, z jaką w epokę Auschwitz wchodzili niektórzy znaczący chrześcijańscy myśliciele. Bierdiajew napisał ten esej na początku 1938 roku jako wyraz chrześcijańskiej reakcji na rasistowski antysemityzm niemieckich nazistów. W tym czasie był on filozofem o europejskiej pozycji.

Ponieważ nasze rozważania traktują o zachodnim chrześcijaństwie, moglibyśmy omówić znane prace największych zachodnich teologów, napisane w tym samym czasie i z taką samą intencją - dania chrześcijańskiego uzasadnienia walce z nazistowskim antysemityzmem. Jednakże idee, które nas teraz zajmują, zostały równie jasno wyrażone i przez tych teologów, i przez Bierdiajewa: mowa jest przecież o ideowej spuściźnie wspólnej różnym

13 F.-W. Marquardt, Christsein nach Auschwitz, „Freiburger Rundbrief Beiträge zur christlich-jüdischen Begegnung" 1979, Jahrgang 31, s. 87. [Friedrich-Wilhelm Marquardt (1928-2002), niemiecki teolog ewangelicki, pionier dialogu żydowsko-chrześcijańskiego, profesor teologii systematycznej na Wolnym Uniwersytecie Berlińskim]. [przyp. tłum.]

${ }^{14}$ N. Bierdiajew, Chrześcijaństwo i antysemityzm. Religijne przeznaczenie Żydów, przeł. M. Kisiel, „ludaica Russica" 2018, nr 1, s. 128-144; tutaj także 0 autorze szkicu i jego charakterystyka, s. 125-127. [przyp. tłum.]

15 F.-W. Marquardt, Christsein nach Auschwitz... 
tradycjom chrześcijańskim, a także liberałom i konserwatystom wewnątrz każdej tradycji.

Tym ważniejsze jest dla nas zwrócenie się właśnie do pracy Bierdiajewa.

Historyk myśli chrześcijańskiej czytając ten tekst dzisiaj w epoce po Auschwitz, kiedy zaczął się żydowsko-chrześcijański dialog, w którym chrześcijanie próbują patrzeć na siebie oczami ofiar Auschwitz (F.-W. Marquardt) i uczą się słuchać głosów Żydów, więc ów historyk zauważy u Bierdiajewa jako autora traktatu o religijnym losie Żydów przede wszystkim brak zainteresowania prawdziwą ich historią. Nie to, żeby Bierdiajew nie znał żydowskiej historii i żydowskiej myśli. Powołuje się przecież na Franza Rosenzweiga i Martina Bubera, na żydowskiego historyka połowy XIX wieku Salvadora, który napisał żywot Jezusa z Nazaretu, na niektóre epizody z historii Żydów ostatnich dwudziestu stuleci. Ale historia Żydów - "to, co naprawdę się stało" — nie jest u Bierdiajewa przedmiotem refleksji, ponieważ jej miejsce zajął u naszego filozofa religijny los Żydów, który przy bliższym rozpoznaniu okazuje się interpretacją ich historii, będącą następstwem nauki chrześcijańskiej.

Już na początku rozprawy Bierdiajewa spotykamy się ze stanowiskiem, które autor traktuje jako coś oczywistego: „Żydzi są narodem szczególnego, wyjątkowego religijnego przeznaczenia. Wybrany naród Boży, z którego wyszedł Mesjasz, nie może mieć losu historycznego, podobnego do losu innych narodów"116.

Nie zapraszam czytelnika do rozmyślań nad tym, jakiego znaczenia nabrałyby te pogańskie słowa o uzasadnionym tragizmie żydowskiego losu, gdyby zabrzmiały na skraju kijowskiego Babiego Jaru po trzech latach od ich napisania - w ostatnie dni września 1941 roku, kiedy w Jarze pogrzebano dziesiątki tysięcy kijowskich Żydów, krajan Bierdiajewa, który pierwsze dwadzieścia cztery lata swojego życia spędził w Kijowie. Nie zapraszam dlatego, że żadnego nowego znaczenia by nie znaleźli: „historyczny los” Żydów, na jaki skazały ich chrześcijańskie narody, miał swoją zwykłą kontynuację w Babim Jarze. Hitlerowcy nie byli pierwszymi, którzy zorganizowali masową eksterminację Żydów na Ukrainie. Ich poprzednikiem był Bohdan Chmielnicki, jeden z najstraszniejszych złoczyńców w historycznej pamięci narodu żydowskiego.

Pomyślmy lepiej nad tym, jakie teologiczne uzasadnienie daje Bierdiajew temu przeznaczeniu: „Wybrany lud Boży [...] odrzucił Mesjasza". Przyjmując ten punkt widzenia, Bierdiajew rozwija te-

${ }^{16}$ N. Bierdiajew, Chrześcijaństwo i antysemityzm ..., s. 131. 
mat chrześcijańskiego antysemityzmu: „Religijny antysemityzm jest $w$ istocie antyjudaizmem $i$ antytalmudyzmem. Religia chrześcijańska rzeczywiście jest wroga religii żydowskiej, ponieważ krystalizowała się po tym, jak Chrystus nie został uznany za oczekiwanego przez Żydów Mesjasza. Judaizm przed Chrystusem i judaizm po Chrystusie to zjawiska duchowo odmienne"17. Wszystkie te klasyczne postulaty teologicznego antysemityzmu Bierdiajew także przyjmuje i idzie jeszcze dalej. Zgadza się - po krótkim wahaniu - ze znanym oskarżeniem Żydów o bogobójstwo i ze stanowiskiem, że na Żydów w ich historii została nałożona klątwa:

"Naród żydowski sam siebie przeklął, zgodził się na to, żeby krew Chrystusa była na nim i na jego dzieciach. Przyjął na siebie odpowiedzialność. [...] Takie oskarżenie. Lecz przecież Żydzi byli pierwsi i uznali Chrystusa. Apostołowie byli Żydami [...]. Naród żydowski krzyczał: 'Ukrzyżuj Go, ukrzyżuj'. Lecz nie wszystkie narody mają niepohamowaną skłonność do ukrzyżowania swoich proroków, nauczycieli i wielkich ludzi. [...] i nie tylko Żydzi ukrzyżowali Chrystusa. Chrześcijanie, albo nazywający siebie chrześcijanami, w ciągu długiej historii swoimi czynami krzyżowali Chrystusa, krzyżowali również swoim antysemityzmem [...]"18.

Tutaj Bierdiajew powtarza stare kłamstwo o Żydach, mające z historycznego punktu widzenia takie samo znaczenie, jak k r wa w a p o t warz, tj. obwinianie Żydów o rytualne zabójstwo pogan, które w wiekach średnich często było pretekstem do masowych prześladowań Żydów.

W istocie rzeczy, co znaczą słowa: „Żydzi odrzucili Chrystusa”? Łatwo dowieść, że odrzucenie Chrystusa, tj. świadoma odmowa uznania przez Żydów Jezusa z Nazaretu za swojego Mesjasza, odnosi się nie do historii żydowskiego narodu, a do historii chrześcijańskiej doktryny. Przyjęło się uważać, że Jezus był ukrzyżowany na mocy decyzji rzymskiego prefekta Judei w 30 roku I wieku ogólnie przyjętego kalendarza. Jego wyznawcy w Palestynie, pierwsza wspólnota chrześcijan składająca się z przestrzegających Torę Żydów, była nieliczna i postrzegana przez tych, którzy wiedzieli o jej istnieniu, jako część ruchu faryzeuszy (zaświadcza o tym historyk Józef Flawiusz). Połowa I wieku w Palestynie charakteryzuje się narastającą intensywnością polityczną, partyzancką walką zelotów (zwolenników "świętej wojny” z Rzymem), z rzymską okupacją, częstą zmianą rzymskich namiestników i zależnych od Rzymian władców z domu Heroda, obfitością religijno-politycznych par-

17 Tamże, s. 136.

18 Tamże, s. 137-138. 
tii i tendencji, pojawieniem się mesjanistycznych pretendentów, z których jednym, prawdopodobnie, był Jezus z Nazaretu. Ogólnie rzecz biorąc, cały kraj powoli wlókł się do Wielkiego Powstania lat 66-73. Klęska powstania, zburzenie Świątyni, utrata przez naród ostatnich resztek systemu narodowo-państwowego, śmierć i oddanie w niewolę setek tysięcy palestyńskich Żydów — wszystko to było początkiem nowej epoki w historii narodu żydowskiego.

Jeśli uznać, że okres ten (przed Powstaniem) odznaczał się wielkim rozkwitem religijnej różnorodności w społeczności żydowskiej, co wyraźnie odróżnia "wczesny judaizm” tamtej epoki od klasycznego judaizmu, który zaczął się formować po klęsce powstania antyrzymskiego, to można powiedzieć tak: $\mathrm{z}$ h is to rycznego punktu widzenia Jezus i jego wyznawcy, tak samo jak np. Jan Chrzciciel i jego wyznawcy, byli tylko jedną z grup wewnątrz społeczności żydowskiej epoki wczesnego judaizmu. Dlatego postawiona przez Bierdiajewa teza, że "naród żydowski odrzucił Mesjasza", nie ma historycznego uza$\mathrm{s}$ a d $\mathrm{n}$ i e $\mathrm{n}$ i a. W historii narodu żydowskiego takiego wydarzenia zwyczajnie nie było.

Nie będę rozpraszał uwagi czytelnika informacjami o historii Żydów końca I oraz II-III wieku, to odciągnie nas bardzo daleko od naszego tematu: "Chrześcijaństwo po Auschwitz". Wspomnę tylko o tym, że na krótko przed rokiem 120., kiedy istniało niebezpieczeństwo całkowitego zakazu praktykowania religii żydowskiej, kiedy przeciwko Rzymianom powstała diaspora i zanosiło się na nowe powstanie w Palestynie, Sanhedryn wyklął Żydów-chrześcijan ze wspólnoty jako niepewnych jej członków (żydowskie źródło nazywa ich "delatorami" [доносчикамu] i "heretykami"). Decyzja ta była jednak tak samo nieważna dla żydowskiej społeczności, jak dla Kościoła, w którym już dawno osiągnęli przewagę chrześcijanie z pogan, i który praktycznie nie zauważył tej decyzji (wszak przestrzegający Tory chrześcijanie żydowskiego pochodzenia byli "heretykami” również z punktu widzenia Kościoła). Ważne jest tutaj, że Kościół na bardzo wczesnym etapie hellenizował się i powiększał swoje szeregi o nawróconych pogan, tak więc w rzeczywistej historii II-III wieku wspólnoty żydowska i chrześcijańska niezbyt się z sobą kontaktowały.

Po raz pierwszy w historii Żydzi jako społeczność otrzymali szansę "odrzucenia Jezusa Chrystusa” dopiero wtedy, kiedy chrześcijaństwo stało się w IV wieku religią państwową w Imperium i Kościół, wsparty siłą państwa, zaczął ograniczać Żydów w prawach, zmuszając ich do ochrzczenia. To ta sama sytuacja, jaką już opisałem słowami Raula Hilberga. 
Ale najbardziej ponurą [зловещую] rolę w historii chrześcijańskich prześladowań Żydów odegrało - uznane przez Bierdiajewa - oskarżenie Żydów o to, że "ukrzyżowali Chrystusa” i teraz dźwigają klątwę, zbiorową odpowiedzialność za to, co zwykło się nazywać zbrodnią bogobójstwa. Potworne konsekwencje teologicznej idei k lą t w y są takie, że po Holokauście nawet Kościół katolicki uznał za konieczność odcięcie się od niej w pamiętnej deklaracji (1965) Soboru Watykańskiego Il: „A choć władze żydowskie wraz ze swymi zwolennikami domagały się śmierci Chrystusa $(J 19,6)^{19}$, jednakże to, co popełniono podczas Jego męki, nie może być przypisane ani wszystkim bez różnicy Żydom wówczas żyjącym, ani Żydom dzisiejszym. Chociaż Kościół jest nowym Ludem Bożym, nie należy przedstawiać Żydów jako odrzuconych ani jako przeklętych przez Boga, rzekomo na podstawie Pisma świętego" 20 .

To $z$ trudem wydobyte $z$ siebie przez Sobór niecałkowite przyznanie się do błędu [полупризнание] pozwoli nam zrozumieć, jak zrodziła się idea mówiąca o tym, że "Żydzi odrzucili Chrystusa”, i jak zrodziło się przekonanie o bogobójstwie i klątwie.

Oczywiście, nasze Pismo Święte, Nowy Testament, zawiera początki nauczania, wedle którego „Żydzi zostali odrzuceni i przeklęci przez Boga". Autorzy deklaracji są przebiegli. Bardziej interesujące jest co innego: soborowa deklaracja jasno wskazuje na to, że nauczanie związane jest z inną ideą teologiczną, także zawartą w Nowym Testamencie - z koncepcją Kościoła jako „nowego Ludu Bożego", czy też nowego Izraela.

Związek tych dwóch kompleksów idei objaśnia znaczącą część nowotestamentowego antyjudaizmu i zrodzonej na jego fundamencie chrześcijańskiej judofobii.

Pomyślmy: co mogła znaczyć dla losu Żydów nowotestamentowa idea Kościoła jako n o w e g o wybranego Ludu Bożego, n o w e go Izraela? Tylko jedno: usunięcie z historii „starego Izraela" jako źródła jedynie prawdziwego nauczania. Dlatego chrześcijanie nazwali żydowskie Pismo Starym Testamentem, to znaczy prawem, które utraciło moc, przeciwstawiając jego treść Nowemu Testamentowi, to znaczy zbawczemu objawieniu Boga w Chrystusie, nowemu boskiemu dekretowi, unieważniającemu stary.

Idea "n o w e g o I z ra e la" zawiera w sobie chrześcijańską wersję historii zbawienia, wersję, która zaczęła pojawiać się już w listach Pawła Apostoła (np. w Liście do Rzymian, 9-11) i w Ewangelii

19 Tu i dalej cytaty z edycji: Pismo Święte Starego i Nowego Testamentu w przekładzie z języków oryginalnych, oprac. zespół biblistów polskich z inicjatywy benedyktynów tynieckich, Pallotinum, Poznań 2000. Lokalizacja bezpośrednio w tekście głównym.

20 Nostra aetate [Deklaracja o stosunku Kościoła do religii niechrześcijańskich], 4. 
Łukasza. Tutaj udzielona zostaje odpowiedź na pytanie: jak byli poganie stali się nowym narodem wybranym? Tak, jak pojęcie narodu wybranego i idea historii zbawienia zostały przejęte przez chrześcijan z Biblii żydowskiej, tak samo odpowiedź na to pytanie powinna była zawierać wzmiankę o "starym" narodzie wybranym.

Tę odpowiedź można streścić na przykład tak: Bóg dopełnił dzieła zbawienia, posyłając do ludzi swojego Syna, który "stał się człowiekiem" jako członek Ludu Bożego — Izraela. Przyjście Chrystusa jest decydującym zdarzeniem w historii zbawienia, to znaczy w historii tego, co zaszło między Bogiem i ludźmi. Wstępnym etapem historii zbawienia, który przygotowywał to zdarzenie, była historia związków między Bogiem i Izraelem, opisana w Starym Testamencie. Każdy człowiek uznający prawdę o zbawieniu w Chrystusie i spełniający określone warunki, stawał się członkiem wspólnoty „zbawionych”, to znaczy Kościoła chrześcijańskiego.

W zwykłej, nieświętej historii odpowiadał temu ten fakt, że Kościół poza granicami Palestyny prawie od samego początku powiększał się o pogan, zhellenizowanych mieszkańców Imperium, których duchowe potrzeby zadowalały się chrześcijańskim nauczaniem, a ono z kolei, już od czasów Pawła (lata 50. I wieku) w swoim rozwoju orientowały się właśnie na świat helleński.

Takie jest pochodzenie wyjściowych postulatów chrześcijańskiego antysemityzmu, zgodnie z którym „Żydzi odrzucili Chrystusa, ukrzyżowali Go i dźwigają wieczną klątwę".

Chrześcijanie uzurpowali sobie żydowską ideę zbawienia, która jako historia święta obejmowała nie tylko całą przeszłość od stworzenia Adama, ale i całą przyszłość - do Dni Ostatnich, kiedy Bóg położy kres światu. Wyrzucili Izrael z tej historii, zastępując go Kościołem i zostawiając Żydom miejsce tylko w przeszłości. Jednocześnie chrześcijanie zawłaszczyli również całą żydowską Biblię jako część pierwszą chrześcijańskiego Pisma Świętego, wytłumaczywszy ją po nowemu - jako zbiór proroctw o Chrystusie.

Wszelako prawdziwy, to znaczy "stary" Izrael wciąż jeszcze żył, i wczesny Kościół póki co musiał mierzyć się z tym faktem, dając mu teologiczną interpretację, której nowotestamentowe źródło już poznaliśmy. Tak zrodził się mit o głupich Żydach, którzy odrzucili Zbawiciela i Go ukrzyżowali. Lecz zbawiennym zdarzeniem okazała się sama śmierć Jezusa, interpretowana przez chrześcijan z pogan jako bolesna ofiara Syna Bożego. I tutaj pojawia się najbardziej ponura strona mitu o głupich Żydach: w świadomości chrześcijańskiej stali się oni sługami diabła i nieprzyjaciółmi Boga, 
celowo uśmiercającymi Zbawiciela i tym samym - mimowolnie - stającymi się narzędziem Opatrzności. Żydzi, na ich nieszczęście, otrzymali funkcjonalnie ważną rolę w chrześcijańskim micie. W Ewangelii Mateusza znajdziemy nie tylko ideę Kościoła jako prawdziwego Izraela, wobec którego spełniają się obietnice Starego Testamentu, ake także hasło chrześcijańskiego antysemityzmu: „A cały lud zawołał: 'Krew Jego na nas i na dzieci nasze'" (Mt 27, 25). Co zaś tyczy się Ewangelii Jana, to jest w niej passus, kluczowy dla chrześcijańskiego wariantu idei żydomasońskiego spisku: „Wy macie diabła za ojca i chcecie spełniać pożądania waszego ojca" (J 8,44). U Jana „Żydzi” w ogóle i „faryzeusze” w szczególności są symbolem niewiary i duchowej ślepoty.

Teraz możemy zrozumieć, co znaczą zacytowane wyżej sądy Bierdiajewa, w szczególności te: „Judaizm przed Chrystusem i judaizm po Chrystusie to zjawiska duchowo odmienne"21. Jasne jest też, dlaczego u Bierdiajewa żydowska świadomość doby narodzin chrześcijaństwa tak bardzo jest „skostniała”, chociaż historyczna ocena byłaby odmienna: ta świadomość była bardzo żywotna i szybko się rozwijała. Nasz filozof zwyczajnie powtarza ogólne punkty chrześcijańskiego nauczania, stanowczo odrzucającego wartość judaizmu w epoce „chrześcijańskiej”. Wiedza historyczna nie potwierdza tego nauczania i dlatego historia nie odgrywa zauważalnej roli w Bierdiajewowskiej koncepcji „religijnego losu Żydów".

W ostatniej części swojego eseju Bierdiajew pyta: „Czy rozwiążemy kwestię żydowską w obrębie historii?"22 Jasnej odpowiedzi nie ma w eseju, ale teraz czytelnik łatwo się domyśli, jakie rozwiązanie wydaje się Bierdiajewowi najlepsze do przyjęcia: oczywiście, zwrócenie się Żydów w stronę chrześcijaństwa. Oto, co pisze: „Żyjemy w epoce nie tylko żydowskiego antysemityzmu, ale i wzrastającej liczby apostazji Żydów do chrześcijaństwa. [...] Niemniej antysemici religijni mogą widzieć jedyne rozwiązanie kwestii żydowskiej w zwrocie narodu żydowskiego w stronę chrześcijaństwa. W tym, z mojego punktu widzenia, ukryta jest wielka prawda"23. Dalsze rozważania prowadzą do tego, że, w odróżnieniu od chrześcijan-antysemitów, Bierdiajew nalega na ścisłe przestrzeganie zasady dobrowolności w tej sprawie i nie bierze pod uwagę tego, że antysemici „przy niezgodzie Żydów na konwersję, gotują im rzeczywisty pogrom"24.

21 N. Bierdiajew, Chrześcijaństwo i antysemityzm..., s. 136.

22 Tamże, s. 141.

23 Tamże.

24 Tamże. 
Konstantin Leontjew nazwał chrześcijaństwo Lwa Tołstoja i Fiodora Dostojewskiego „różowym"25. Religijne przekonania Nikołaja Bierdiajewa można byłoby na podstawie tego eseju określić jako "chrześcijaństwo z ludzką twarzą", to jest jako „przywiązanie do tradycji minus pogrom". Pozycja ta podkreślana jest u Bierdiajewa frazami, które teraz postrzegane są jako nie do przyjęcia pseudopobożny fałsz: „Dla konwersji Żydów na chrześcijaństwo bardzo ważne jest to, by sami chrześcijanie przeszli na chrześcijaństwo, to znaczy stali się chrześcijanami nie formalnymi a rzeczywistymi" ${ }^{\prime 26}$.

Czym zaś uargumentowane jest wskazane w eseju przekonanie Bierdiajewa, wedle którego chrześcijaństwo w istocie rzeczy wyklucza antysemityzm, a antysemityzm "musi wyjawić swoją antychrześcijańską naturę"? Bierdiajew przytacza dwa przykłady. Jeden z nich jest zewnętrzny: niemiecki rasizm ma „zupełnie niechrześcijańskie korzenie”. Filozof ma na myśli historyczny fakt dystansowania się narodowych socjalistów od chrześcijaństwa. Chrześcijańskie dowody właściwie prowadzą do przypominania o żydowskich korzeniach chrześcijaństwa. Widzieliśmy już, że analiza "żydowskich korzeni" pomaga objaśnić charakter chrześcijańskiej judofobii. Wszelako argumentom przeciwko antysemityzmowi przypomnienie to może służyć jedynie na płaszczyźnie emocjonalnej, poniekąd w eksklamacjach o żydowskości Marii, Jezusa i Apostołów, od których zaczyna się rozprawa. Historia pokazuje całkowitą nieefektywność takich argumentów i odwołań do "wspólnego dziedzictwa": niestety, nigdy one jeszcze nie pomogły.

Rozumiemy, że u podstaw sądów Bierdiajewa leży wyobrażenie o chrześcijaństwie jako kwintesencji wszystkiego, co wielkie i piękne. Wyobrażenie to możemy odnaleźć w różnych wykwintnych sentencjach, na przykład takich: „Ci, którzy nienawidzą i dokonują ukrzyżowań nie mogą być nazwani chrześcijanami, bez względu na to, ile by nie bili pokłonów. [...] Chrześcijanom przede wszystkim przyszło bronić prawdy [...]. Właśnie chrześcijanom przyszło bronić godności człowieka, wartości ludzkiej osoby, każdej ludzkiej osoby, niezależnie od rasy $[\ldots]^{\prime 27}$.

25 К.Н. Леонтьев, Наши новые христиане. Ф.М. Достоевский и гр. Лев Толстой. По поводу речи Достоевского на празднике Пушкина и повести гр. Толстого „Чем люди живы?", тип. Е.И. Погодиной, Москва 1882, https://antimodern.ru/wp-content/uploads/Hashi_novye_hristiane.pdf [07.12.2019]. [Konstantin Nikołajewicz Leontjew (1831-1891), lekarz, filozof, pisarz, przedstawiciel religijnej myśli konserwatywnej, czasem nazywany „rosyjskim Nieztschem”. Nikołaj Bierdiajew w studium Константин Леонтьев (YMCA-Press, Париж 1926) twierdził jednakże, że trudno mówić o immoralizmie Leontjewa, ponieważ jest to „inna moralność". [Przyp. tłum.].

26 N. Bierdiajew, Chrześcijaństwo i antysemityzm..., s. 142.

27 Tamże. 
Może i tak. Bierdiajew wszakże, jak widać, nie pomyślał o tym, że Żyd, członek religijnej wspólnoty Izraela, może okazać się religijnie ważny i dla niego, Bierdiajewa, właśnie jako Żyd, a nie potencjalny wychrzta.

Kończąc rozbiór tego tekstu, chciałbym zapewnić czytelnika, że nie dążyłem do zbudowania negatywnej opinii o Nikołaju Bierdiajewie. Podobnie jak wielu moich rówieśników, którzy wyrośli w środowisku niereligijnym, z książek Bierdiajewa zaczerpnąłem w swoim czasie pierwsze refleksje o chrześcijaństwie i zawsze będę za to wdzięczny ich autorowi.

*

Ostatecznie, powtarzam, mówimy o wspólnym dziedzictwie chrześcijańskiej teologii, o tym, co wydawało się oczywistością przed Auschwitz. Największy z rosyjskich filozofów, Władimir Sołowjow, znany ze swojego judofilstwa, który posiadał ogromną wiedzę w zakresie historii Żydów i literatury talmudycznej, który szczególnie wypowiadał się w obronie Talmudu przeciwko antysemickim oszczerstwom, podzielił jednak wszystkie te wspólne miejsca, które przeanalizowaliśmy na przykładzie eseju Bierdiajewa. Dopiero po Holokauście zaczął zmieniać się sam język teologii.

Odesłanie do rosyjskich pisarzy chrześcijańskich w związku z naszym tematem ważne jest również i dlatego, że Auschwitz nie powinno być dla nas tylko nazwą-szyfrem, przywołującym w świadomości obraz Gułagu. Budowanie takich kulturowych relacji skojarzeniowych samo w sobie byłoby rzeczą niegodną, ponieważ $\mathrm{każ} d a$ niewinna ofiara jest wyjątkowa i nie powinna stawać się powodem do politycznych spekulacji. Poza tym, nie mamy prawa przeciwstawiać Auschwitz Gułagowi wedle zasady "obce - swoje". Przecież znacząca część Holokaustu działa się na terenie naszego kraju. Z sześciu milionów Żydów, zamordowanych w czasie Holokaustu, półtora miliona było obywatelami ZSRR $w$ dawnych (do 1939 roku) granicach. Hitlerowcy nie mogliby tego zrobić bez pomocy rdzennych mieszkańców. Tak samo jak we wszystkich okupowanych krajach, los Żydów często bywał w rękach narodowej większości. Każdy wie, jak Duńczycy uratowali praktycznie wszystkich swoich Żydów. O wiele mniej wie się u nas o tym, że rdzenni mieszkańcy okupowanych przez nazistów terytoriów ZSRR aktywnie uczestniczyli w eksterminacji Żydów. A przecież historycy wiedzą i o pogromach, które miejscowi mieszkańcy urządzali po wy- 
cofaniu się Armii Czerwonej i przed wkroczeniem hitlerowców ${ }^{28}$. A w Izraelu znane są nazwiska "sprawiedliwych wśród narodów świata" z naszego kraju - tych, którzy ratowali Żydów w czasie Katastrofy.

\section{III}

Dotąd starałem się wyjaśnić - choćby tylko w części - rzecz następującą: dlaczego w czasie Holokaustu Kościoły nie wystąpiły w obronie Żydów; dlaczego po Holokauście chrześcijanie nie mogą żyć w "świecie niepodważalnych twierdzeń", w tym także i dogmatycznych twierdzeń o Jezusie z Nazaretu; dlaczego wśród zachodnich teologów pojawiła się myśl o tym, że zrozumienie Holokaustu powinno mieć dla chrześcijan doktrynalne konsekwencje.

Teraz zwrócimy się ku semantyce „teologii po Auschwitz".

Oto co mówi o możliwych kierunkach rewizji, kierując swoje słowa do chrześcijan, żydowski teolog Emil Fackenheim: „Warto zapytać, [...] czy zmiany w chrześcijańskim podejściu do Żydów cechuje radykalizm, będący po Auschwitz absolutną koniecznością. [...] Prawda [...] według mnie wygląda tak, że instytucjom chrześcijańskim najłatwiej przyjdzie odrzucić odwieczne oskarżenie o bogobójstwo, trudniej dostrzec nowotestamentowe korzenie antysemityzmu, a najtrudniej sprostać temu, że Żydzi i judaizm nadal istnieją. Stając wobec niewygodnego żydowskiego trwania po wyłonieniu się chrześcijaństwa, teolodzy postrzegali judaizm jako skamielinę, anachronizm, cień. Niełatwo zatem odwrócić doktrynę wyznawaną przez dwa tysiąclecia [...] i uznać, że zarówno Żydzi, jak i judaizm trwają nieprzerwanie przez całą epokę chrześcijańską" ${ }^{\prime 29}$.

Stanowisko Fackenheima pokrywa się z tym, co zanotowałem przy analizie rozprawy Bierdiajewa. I teraz możemy spojrzeć na rzecz szerzej. Mowa jest przecież nie o chirurgicznym leczeniu "chorego" chrześcijaństwa przez wycięcie niewygodnych elementów nauczania, ani też o bezwarunkowej kapitulacji, to jest nie o uznaniu wiary chrześcijańskiej za coś złośliwego, niezdolnego do przywrócenia człowiekowi nadziei. Nie, mowa jest o orienta-

280 pogromach na Litwie zob. D. Levin, On the relations between the Baltic peoples and their Jewish neighbours before, during and after World War II, "Holocaust and genocide studies. An international journal" [0xford] 1990, vol. 5, nr 1, s. 53-66. 0 pogromach we Lwowie zob. S. Redlich, Metropolitan Andrei Sheptyts'kyi, Ukranians and Jews during and after the Holocaust, tamże, s. 39-51. 0 udziale Ukraińców, Litwinów i Białorusinów w eksterminacji Żydów na terytoriach okupowanych przez nazistów zob. także fundamentalną monografię Nory Levin o Holokauście: N. Levin, The Holocaust. The destruction of European Jewry 19331945, Schocken, New York 1973, s. 247 i nast.

29 E.L. Fackenheim, Żydowska wiara a Holocaust..., s. 357. 
cji w świecie, gdzie już nie ma niepodważalnych twierdzeń. Tym samym, powstaje konieczność twórczego odnowienia fundamentów chrześcijańskiej tożsamości.

Oto co pisał o pierwszej chrześcijańskiej tożsamości, która runęła po Katastrofie, chrześcijański historyk Robert Ericksen: „Chrześcijaństwo tak bardzo zmieszało się z szeregiem różnych czynników kulturowych, że nie można go już wyodrębnić w czystej postaci. Chrześcijaństwo to niemiecka kultura. Chrześcijaństwo to moralność klasy średniej. Chrześcijaństwo to szacunek do władzy. Chrześcijaństwo dla prawa i porządku. Chrześcijaństwo po stronie 'statecznych' grup społecznych w ich walce $z$ anarchią. Właśnie w podobnych oglądach jest przyczyna tego, że bardzo wielu chrześcijan uznało ruch narodowosocjalistyczny za religijne odrodzenie $^{\prime \prime 30}$.

Tak więc, konieczna jest nowa koncepcja relacji między Kościołem i państwem, konieczne nowe przemyślenie związków między tym, co "chrześcijańskie" i tym, co "narodowe”, i — rzecz najważniejsza - nowe ujęcie zagadnienia prawdy religijnej. To, że chrześcijaństwo przed Auschwitz nie było zdolne do uznania niezależnej wartości judaizmu, jego samowystarczalności, powinniśmy interpretować jako wskazanie centralnego punktu nowego rozumienia religijnej prawdy w "teologii po Auschwitz". Mówimy o treści chrześcijańskiego Credo i związanej z nim kwestii uniwersalnego dążenia chrześcijaństwa do wyrażenia pełnej prawdy, o jego dążeniu do wykluczenia lub ograniczenia prawdy innych religii i światopoglądów.

Wrócimy do tej kwestii po krótkiej charakterystyce problematyki: „chrześcijańskie” a "narodowe”. W teologii kultury przed Auschwitz panował następujący aksjomat: chrześcijaństwo jest $\mathrm{fi}$ larem wartości kultury narodowej. Kultura narodowa jest wartościowa o tyle, o ile jest kulturą chrześcijańską.

W bardziej wulgarnym wariancie ta relacja jest odwrócona, a chrześcijaństwo jest postrzegane jako część kultury narodowej. W praktyce te koncepcje się zlewają, są nierozdzielne, i dlatego możemy obserwować „ruchy narodowo-religijne".

I tutaj "teologia po Auschwitz" dochodzi do wniosku, że porażka chrześcijaństwa w nazistowskich Niemczech w obliczu Holokau-

30 R. Ericksen, Theologians under Hitler (Gerhard Kittel, Paul Althaus and Emanuel Hirsch), Yale University Press, New Haven 1985, s. 46. [Robert P. Ericksen, ur. 1945, historyk, doktorat uzyskał w London School of Economics, profesor Pacific Lutheran University, członek Komitetu ds. Etyki, Religii i Holokaustu w United States Holocaust Memorial Museum. Studium Theologians under Hitler otrzymało wyróżnienie m.in. Ligi Antydefamacyjnej (Anti-Defamation League) i zostało przełożone m.in. na niemiecki, duński i japoński [przyp. tłum.]. 
stu postawiła pod znakiem zapytania samą możliwość połączenia czynników "chrześcijańskiego" z „narodowym”.

*

A teraz, wspomagając się cytowanymi już słowami Roberta Ericksena, sformułuję centralny dla rozpatrywanego kierunku teologicznego problem: jak mogłoby wyglądać po Holokauście „chrześcijaństwo wyodrębnione w czystej postaci"? Rozmyślania nad tym, co nazywamy "teologią po Auschwitz", prowadzą do następującego wniosku: byłoby to chrześcijaństwo, które wypracowałoby własną polityczną kulturę, niezależną od charakteru reżimów politycznych; chrześcijaństwo odrzucające jakąkolwiek obsługę narodowych wartości i tradycji; w końcu, chrześcijaństwo relatywizujące własne dążenia do głoszenia absolutnej prawdy i eliminujące z tego dążenia postawy misyjne. Jak widzieliśmy, to ostatnie udaje się z największym trudem. Znany katolicki teolog Johann Baptist Metz pyta w swojej rozprawie: „Czy chrześcijaństwo jest gotowe i zdolne - a jeśli tak, to w jakiej mierze — uznać mesjanistyczną tradycję judaizmu w jej niezbywalnej tożsamości, uznać jej wciąż trwającą mesjanistyczną godność, a przy tym nie zdradzać ani nie obniżać rangi chrystologicznej tajemnicy zawartej w chrześcijaństwie?" 31

Sformułowałbym tę kwestię bardziej ogólnie: jak można ze śmiertelną powagą odnosić się do swojej prawdy i z taką samą powagą przyjmować istnienie „cudzych” prawd? Czy pluralizm może być czymś więcej niż sposobem pokojowego współistnienia w światopoglądowo podzielonym świecie? Czy jest możliwe, aby pluralizm stał się pozytywną wartością w samym chrześcijaństwie, to znaczy chrześcijańs ką wartością?

\section{IV}

Ale aby odpowiedzieć na to pytanie, powinienem zwrócić się do pojęcia w i a ry. Jeśli wiara jest zgodą na prawdę wielu twierdzeń, to jest ona, oczywiście, niezgodna z wątpieniem, jakie mamy przy poważnym odnoszeniu się do cudzych poglądów. Zwykliśmy mówić w takich przypadkach: wątpienie niszczy wiarę. Jeśli jednak, w ślad za Paulem Tillichem, zdefiniujemy wiarę jako poch w y-

31 J.B. Metz, Jenseits bürgerlicher Religion..., s. 36. 
cenie przez Nieuwarunkowane ("pochwycenie” w sensie „bycia posiadanym”) 32, to zrozumiemy wiarę jako sposób istnienia i wątpienie stanie się koniecznym elementem takiej wiary. Jeśli wiara jako bezwarunkowe oddanie („pochwycenie”) związana jest z ryzykiem (to przekonanie właściwe jest wielu tradycjom chrześcijańskim), to, jak mówi Paul Tillich, wątpienie wierzącego jest „wątpieniem tego, kto jest najgłębiej zatroskany o pewną treść konkretną" ${ }^{33}$. Jest to wątpienie egzystencjalne, różniące się od metodologicznego wątpienia uczonego i dogmatycznego wątpienia sceptyka. Wiara jako bezwarunkowe oddanie włącza w siebie również wątpienie. Wątpienie okazuje się strukturalnym elementem wiary, a nie stanem psychicznym.

Chciałbym pokazać, że pojęcie wiary, związane z tymi rozmyślaniami nad „teologią po Auschwitz”, zaprzeczające własnym uniwersalnym twierdzeniom i, oczywiście, odpowiadające takiemu rozumieniu wiary pojęcie o Bogu — bardziej jest pobożne niż absolutystyczne i „niepluralistyczne” pojęcie wiary. Łatwo wszak pojąć, że wiara, włączając ryzyko i wątpienie w swoją strukturę, ma na uwadze bardziej „wysublimowanego”, bardziej „boskiego” Boga niż wiara żyjąca „w świecie niepodważalnych twierdzeń”. W istocie rzeczy, wiara pozbawiona elementów ryzyka i męstwa traci charakter wiary i przyjmuje cechy jedynie prawdziwej ideologii. Zachodzi tutaj bezbożne pomniejszenie Boga, sprowadzenie go do pozycji bożka.

Żeby wyjaśnić moje stanowisko o pluralizmie jako szczególnej wartości chrześcijańskiej, zwrócę się do tradycyjnego w zachodniej myśli teologicznej rozróżnienia na to, co „ostateczne” i „przedostateczne". W pełni autentyczne (nie budzi wątpliwości, nie jest związane z ryzykiem) jest tylko bezwarunkowe Nieuwarunkowanie, realność, która jest mi dana tak samo bezpośrednio, jak moje własne "ja”" (to znaczy pochwycenie przez to, co dotyczy mnie bezwarunkowo). To obszar „ostatecznego". Ale przyjęcie konkretnej treści Bezwarunkowego jest aktem męstwa, związanego z ryzykiem.

Chrześcijanin może powiedzieć: Jezus z Nazaretu stał się dla mnie treścią mojej „ostateczności”, treścią tego, co dotyczy mnie bezwarunkowo. W nim, Jezusie z Nazaretu, Bóg odkrył mi wszystko, co potrzebne do tego, aby moje życie wypełniło się sensem. Apostoł Paweł w Liście do Galatów napisał: „Jeżeli zaś usprawiedliwienie dokonuje się przez Prawo, to Chrystus umarł na darmo" (Ga 2,21). (Nawiasem mówiąc, jest to klasyczny wyraz absolutnego

32 P. Tillich, Pytanie o Nieuwarunkowane..., s. 29.

33 P. Tillich, Dynamika wiary..., s. 45. 
twierdzenia chrześcijaństwa!). Tak więc i dla mnie znaczenie Dobrej Nowiny (Ewangelia) wyraża się w podobnym okresie warunkowym: „Jeżeli nie biorę na siebie ostatecznej odpowiedzialności, jeśli uchylam się od niej, to Chrystus umarł na darmo". Teraz spróbuję wyjaśnić, co to znaczy.

Znamy słowa, które w naszej świadomości związane są z nazwiskiem niemieckiego mistyka wieku XVII Johannesa Schefflera (Angelusa Silesiusa): "Jeśli mnie nie ma, to i Boga nie ma”"34. Podobne słowa spotyka się w mistycznych tradycjach różnych religii. Mistyk próbuje wyrazić swoje doświadczenie: istnienie Boga w jakimś sensie „zależy” od istnienia człowieka. A w Encyclopaedia Britannica, w artykule Antropologia filozoficzna, nieoczekiwanie znalazłem słowa, z innej strony dotykające tego samego przedmiotu: "Zadziwiająca korespondencja jest między tematami śmierci Boga i śmierci człowieka. ["Teologia śmierci Boga" była popularna na Zachodzie w latach 60. XX wieku -S.L.]. Wydaje się, że ujawnia ona głębszy wzajemny związek między teologią i antropologią [...]. Jeżeli w przeszłości myśl dążyła przede wszystkim do tego, żeby udowodnić istnienie Boga, to zasadniczą trudnością dla dzisiejszej myśli jest udowodnienie istnienia człowieka"35. (Myślę, że nie trzeba szczegółowo wyjaśniać, że pytanie "o istnienie człowieka" pojawia się w świecie, gdzie istniał Auschwitz).

Oto więc i moje rozumienie Nowiny: w Jezusie Bóg już zrobił wszystko, co zależało od Niego. A teraz sens życia i śmierci Jezusa zależy ode mnie. Jeśli nie biorę na siebie ciężaru świadczenia o Jezusie, o którym mówi Nowy Testament, to on "umarł na darmo".

Takie jest doświadczenie przyjęcia semantycznego jądra chrześcijańskiej Nowiny. I temu odpowiada pojęcie Boga jako Tego, Który może dać mi siłę wzięcia na siebie tego brzemienia.

Oczywiście, taka teologia i taka chrystologia nie będą przedstawiać twierdzeń absolutnych na posiadanie pełni prawdy. Przyjąłem tę wiarę w Kościele, lecz nie mogę ręczyć, że i inni "uwierzą" w nią. Nawet nie odczuwam potrzeby "przekazania”, to znaczy jakoś jej nazwania.

Moja bezwarunkowość i „ostateczność” nie obowiązują innych. Nie mogę im wskazać drogi do "usprawiedliwienia” i „zbawienia”,

34 Odwołanie do Cherubinischer Wandersmann Angelusa Silesiusa, ks. 2, 178 [Alls steht im Jch und Du (Schöpffer und Geschöpffe)]: „Nichts ist als Jch und Du: und wenn wir zwey nicht seyn / So ist GOtt nicht mehr G0tt / und fällt der Himmel ein”. W przekładzie Nikołaja Biełocwietowa: „Есть только Ты и я! И если бы я не был,/ То не был бы Ты Бог и рухнуло бы небо!" (Ангел Силезский, Избранные двустишия из Херувимского Странника, przekł. Н. Белоцветова. Гамаюн, Берлин 1926; http://bdn-steiner.ru/modules. php?name $=$ Poezia\&go=page\&pid=10101 [08.12.2019] [przyp. tłum.].

35 Encyclopaedia Britannica, 15th ed., vol.1, Chicago [et al] 1974, s.v. Anthropology, Philosophical. 
a nawet nie mogę wiedzieć, czy sens ich życia z Bogiem jest ustalony w tych czy innych terminach. I tutaj odkrywa się przestrzeń dla chrześcijańskiego pluralizmu.

\section{Rosyjskie prawosławie i nowy patriotyzm}

W pierwszej części tej pracy była mowa o rozumieniu Holokaustu przez zachodnich chrześcijan, eksterminacji europejskich Żydów i - w związku z tym - o specyfice chrześcijańskich odniesień do "kwestii żydowskiej”. Próbowałem pokazać, że ten poniekąd szczegółowy temat pozwala zobaczyć coś ważnego w "minionym i obecnym obrazie chrześcijańskiego bytu” i nawet pozwala zamyślić się nad „istotą chrześcijaństwa inaczej niż ją dotąd pojmowaliśmy"36.

Ale, naturalnie, naszą główną troską i punktem wyjścia wszystkich dyskusji jest wzrost agresywnego nacjonalizmu i antysemityzmu w społeczeństwie rosyjskim.

I tutaj temat żydowski wydaje się także wyłącznie osobisty. Pisarz Boris Chazanow wypowiedział słowa, nad którymi należy się zastanowić: "Antysemityzm to uniwersalna szkoła zła"37. W ostatnim czasie niemało mówi się o podobieństwie rosyjskiego nacjonalizmu do niemieckiego nazizmu. A dla narodowych socjalistów antysemityzm był czymś o wiele ważniejszym niż tylko jednym ze zwykłych punktów ich programu. Jak wiadomo, podział ludzkości na „aryjczyków” i „niearyjczyków” (pod którymi rozumiano przede wszystkim Żydów) stanowił filar ich rasistowskiej mitologii. Emil Fackenheim napisał: „Żydzi nie byli w Auschwitz gatunkiem 'rasy niższej', lecz prototypem, na którego podstawie ową 'rasę niższą' definiowano. Jako masowy ruch, nazistowska rewolucja zaczęła odnosić sukcesy dopiero po przekształceniu się w rewolucję antyżydowską; gdy zaś z hukiem poczęły się

36 F.-W. Marquardt, Christsein nach Auschwitz...

37 Б. Хазанов, Возвращение Агасвера, w: tegoż, Ветер изгнания. Эссеистика, Сибирский хронограф Возвращение, Новосибирск-Москва 2003 (toż w wersji online: ImWerdenVerlag, München 2006, s. 35, https://imwerden.de/pdf/khazanov_veter_izgnaniya.pdf [1.12.2019]). Chazanow pisze dokładniej: „Nie możemy zapominać, że antysemityzm jest ludzką szkołą zła i nie bez powodu wielowiekowa edukacja w tej szkole zakończyła się komorami gazowymi i krematoriami [печами]". [Boris Chazanow, właśc. Giennadij Moisiejewicz Fajbusowicz, ur. 16 stycznia 1928 roku w Leningradzie. Prozaik, eseista, tłumacz dzieł Leibniza. W latach 1949-1955 więzień polityczny, później pracował m.in. jako lekarz. Prozę i eseje publikował w samizdacie i wydawnictwach poza Rosją, w Rosji natomiast jako Giennadij Szingariew był autorek książek popularnonaukowych. W 1982 roku wyemigrował do Niemiec, gdzie związał się m.in. z Radiem Swoboda. Mieszka w Monachium. Autor znanej powieści Час короля (1978), u której podstaw legła legenda o duńskim królu Christianie X, który na znak solidarności z prześladowanymi Żydami w czasie okupacji Danii miał podobno nosić opaskę z sześcioramienną gwiazdą]. [przyp. tłum.] 
walić wszystkie jego dokonania, jeden cel pozostał niezmienny: zagłada Żydów"38.

Mówiąc o zbieżności tych dwóch obrazów agresywnego nacjonalizmu, proponuję pozostać na gruncie historycznego do nich podejścia i wcale nie dążę do tego, aby na czytelniku sprawić wrażenie, że są one tożsame. Ten typ nacjonalizmu, który w dzisiejszym życiu politycznym jest silnie związany z Frontem Narodowo-Patriotycznym "Pamięć" ${ }^{\prime \prime}$, powstał w warunkach tylko z daleka przypominających Niemcy po I wojnie światowej. I, naturalnie, chwytliwe podobieństwa i stwierdzenie prawdziwych podobieństw nie zastąpią analizy historycznej.

Dlatego, opierając się na tym, co powiedziano wcześniej i zgodnie z ogólnym planem pierwszej części tej pracy, postaram się pokrótce nakreślić moje rozumienie "nowego patriotyzmu" (uczestników ruchu typu "Pamięć" będę nazywał patriotami, używając ich własnych samookreśleń). Następnie - i to jest dla mnie najważniejsze - przeanalizuję prawosławne oceny tego ruchu, oceny, które uważam za typowe. Mam nadzieję, że takie podejście pozwoli nam dostrzec niektóre zasadnicze cechy współczesnego rosyjskiego prawosławia.

Nowy patriotyzm często porównuje się do czarnoseciństwa, rasistowskiego nacjonalizmu typu protonazistowskiego, który pojawił się na powierzchni politycznego życia Rosji na początku XX wieku i stał się aktywny w okresie demokratycznych reform, jakie zaczęły się w roku 1905. Następnie rosyjski nacjonalizm tego odłamu rozwijał się na emigracji, nawet na Dalekim Wschodzie istniała Rosyjska Partia Faszystowska ze stolicą w Harbinie. Historyczny związek między czarnoseciństwem i nowym patriotyzmem jest niewątpliwy (jeden ruch przejął od drugiego w darze Protokoły Mędrców Syjonu), ale znaki ciągłości nie powinny przesłaniać s p e cyfiki nowego patriotyzmu.

Spróbujemy wyodrębnić te specyficzne cechy nowego patriotyzmu, które są uwarunkowane jego powstaniem wewnątrz społeczności komunistycznej. Przedkładam podwójną interpretację tej specyfiki:

38 E.L. Fackenheim, Żydowska wiara a Holocaust..., s. 349.

39 Национально-патриотический фронт «Память» — ultraprawicowa, antysemicka organizacja monarchistyczna, założona w Moskwie w 1980 r. Szerzej: В.В. Прибыловский, «Память». Документы и тексты, Информационно-экспертная группа «Панорама», Москва 1991. 
1. Treść ideologii nowego patriotyzmu odwołuje się głównie do rasistowskiej myśli, bądź to rosyjskiej, niemieckiej lub zachodnioeuropejskiej w ogóle (na przykład do angielskich i francuskich teorii rasowych przeszłego stulecia).

2. Struktura nowej ideologii narodowej w większości określona jest przez strukturę ideologii komunistycznej, która do niedawna prawie niepodzielnie panowała w naszym kraju.

Konsekwentnie starając się unikać myślenia "na wielką skalę", powinniśmy określić, co rozumiemy przez społeczność komunistyczną i ideologię komunistyczną. Ale to bardzo odwiodłoby nas od istoty zagadnienia, ponieważ nie ma zadowalającej definicji tych pojęć i dlatego po prostu wyszczególnię te cechy ideologii komunistycznej, które są istotne dla naszego tematu.

Zatem przez strukturalne cechy ideologii komunistycznej rozumiemy totalność i dualizm. Totalność jest dążeniem ideologii do udzielenia odpowiedzi na wszystkie pytania ludzkiej egzystencji, objęcia przez siebie wszystkiego bez pozostawiania pytań otwartych. Dualizm to wyraźna definicja jasnych i ciemnych biegunów, obraz rzeczywistości społecznej polaryzowany według zasady: "swoi - obcy”, „przyjaciele - wrogowie”, „postępowa ludzkość siły reakcji".

Można powiedzieć, że komunizm w Rosji sformułował taką polityczną kulturę mas, wewnątrz której zrodził się nacjonalizm „Pamięci”. Przecież jeśli rozpatrywać komunizm i rasizm jako nauki ścisłe, które pojawiły się w Europie XIX wieku i stały się ideologiami mas $w$ wieku XX, to trzeba byłoby zwrócić uwagę na to, co je łączy: na antyliberalny patos, na powszechny sprzeciw wobec wartości liberalnych.

W nowym patriotyzmie, podobnie jak w komunizmie, jest widoczna totalność, zaspokajająca potrzebę prostej i wszechobejmującej interpretacji społecznego doświadczenia. Co się tyczy dualizmu, to najnowszy nacjonalizm uważa za ciemny biegun, źródło wszelkiego zła, "syjonistów”, tworzących spisek w celu zapanowania nad całym światem. Być może, teraz już otwarcie, a nie eufemistycznie, mówi się właśnie o spisku "syjonistycznym", a nie po prostu „żydowskim” czy „żydo-masońskim”. W tym, że właśnie „syjonizm" stał się słowem kluczem dla oznaczenia wroga w ideologii nowego patriotyzmu, wypowiedział się również wpływ oficjalnej propagandy antysyjonistycznej, wpływ stworzonego przez nią mitycznego obrazu syjonizmu.

Widzimy więc, że również i dla najnowszego rosyjskiego nacjonalizmu "kwestia żydowska" nie jest czymś szczególnym. Rasistowski antysemityzm w formie mitu antysyjonistycznego i tutaj 
sytuuje się w samym centrum programu. Można powiedzieć i tak: antysemityzm pozostaje jedynym jęz y k i e m nacjonalizmu.

Przypomina się znany aforyzm Hegla z wprowadzenia do jego Filozofii historii: „Historia uczy, że ludzkość niczego się z niej nie nauczyła".

Oczywiście, chciałoby się mieć nadzieję, że historia mimo to nauczy czegoś również zwolenników "nowego patriotyzmu”. Ale nas prostych ludzi, obywateli nie pałających miłością do ani jednego "izmu”, historia Auschwitz i historia Gułagu powinna była nauczyć tego, że najstraszniejsze w ideologiach nienawidzących człowieka jest dzielenie rzeczywistości na Absolutne Dobro i Absolutne Zło, identyfikacja Zła z jakąkolwiek społecznością ludzką i wynikające stąd "ostateczne rozwiązanie” problemu Zła, próba zniszczenia tych ludzi, których ideologia wskazała jako nosicieli Zła, ucieleśnienie mrocznego przeciwieństwa.

Mam przed sobą dwa teksty, których autorzy próbują dać krytyczną analizę agresywnego rosyjskiego nacjonalizmu z p ra w o sław nego punktu widzenia. Jest to artykuł Gleba Aniszczenki Kto jest winny ${ }^{40}$ i list otwarty Wiktora Aksiuczyca do Władimira Osipowa, redaktora pisma „Ziemla"41. Mamy prawo oceniać oba te artykuły razem, ponieważ Aksiuczyc pisze: „Mój stosunek do ‘Pamięci' jest całkowicie zgodny z poglądami mojego współwydawcy dziennika 'Wybor' Gleba Aniszczenki"42.

Autorzy obu tekstów rozważają analizowany w części pierwszej tej pracy postulat, wedle którego chrześcijaństwo tworzy w a r t o ściowy rdzeń narodowej kultury, a kultura narodowa jest wartościowa w podobnej mierze, co kultura chrześcijańska.

40 Г. Анищенко, Кто виноват? « Гласность» 1988, nr 15 (февраль). [Gleb Aleksandowicz Aniszczenko, ur. 13 października 1952 roku w Moskwie, pisarz, pedagog, działacz społeczny i religijny. Wlatach 1987-1992 wydawca (wraz z Wiktorem Aksiuczycem) i redaktor naczelny literacko-filozoficznego czasopisma "Wybor”, poświęconego rosyjskiej kulturze chrześcijańskiej. Autor m.in. zbiorów prac: Православие. Литература. Революция, Паломник, Москва 2012; Литературный справочник, Форум, Москва 2012 [przyp. tłum.].

41 «Гласность» 1988, nr 18 (апрель). [Wiktor Władimirowicz Aksiuczyc, ur. 29 sierpnia 1949 roku we wsi Wardomicze na Białorusi, filozof, teolog, publicysta, polityk, lider Rosyjskiego Ruchu Chrześcijańsko-Demokratycznego (Российское христианское демократическое движение), zwolennik monarchii konstytucyjnej. Mocno zaangażowany w działalność polityczną po roku 1990. Od 2019 roku prezes fundacji Русские университеты. Najważniejszą jego pracą pozostaje Идеократия в России, Выбор, Москва 1995; wznowienie: Direct Media, Москва-Берлин 2019. Władimir Nikołajewicz Osipow, ur. 9 sierpnia 1939 roku w Słancy, publicysta, działacz społeczny, polityk, członek Rady Głównej monarchistyczno-prawosławnego Związku Narodu Rosyjskiego (Союз Русского Народа), przedrewolucyjnej organizacji reaktywowanej w roku 2004. Do głównych jego prac należą Корень нации. Записки русофила, Алгоритм, Москва 2008; Возрождение русской идеологии, Алгоритм, Москва 2012 [przyp. tłum.]..

42 Tamże. 
Widzieliśmy, że po Auschwitz w zachodniej myśli chrześcijańskiej postulat ten został postawiony pod znakiem zapytania. Co więcej, na drodze wielkiego przewartościowania wartości, które zaczęło się w epoce po Auschwitz, teologowie chrześcijańscy zakwestionowali samą możliwość złączenia tego, co „chrześcijańskie" z tym, co "narodowe". Tymczasem, bez względu na historyczną katastrofę, jaką przeżył nasz naród, znaczeniowo podobny ruch nie zrodził się w rosyjskim chrześcijaństwie.

Zdaniem Aniszczenki, „dla utwierdzenia chrześcijańskiego światopoglądu (a to jest również fundament rosyjskiej świadomości narodowej) trzeba koniecznie dążyć do pozytywnego, pokojowego rozwiązania problemów, a nie do rozniecania wrogości i gniewu, nie do sprzyjania narodowej nieodpowiedzialności".

Aksiuczyc uważa, że "pośród [wielu] zniszczeń w naszym kraju, szczególnie nadwyrężona została świadomość patriotyczna, przez dziesięciolecia wypalano ją z naszych dusz. To oc z y wi ste, że nie może się ona odrodzić bezboleśnie [podkr. - S.L.]. [...] Długi proces naszego ozdrowienia wymaga od nas wzajemnego cierpienia i cierpliwości, zrozumienia i uczestnictwa, pokuty i przebaczenia. To znaczy tego, co pragnęło w nas wpoić Rosyjskie Prawosławie".

Rozmyślając nad uwarunkowaniami chrześcijańskiej krytyki najnowszego rosyjskiego nacjonalizmu, zauważyłem dwie cechy szczególne.

1. Chrześcijański pogląd na to zagadnienie podskórnie odwołuje się do stanowiska ideologicznego, które nazwałbym „klasycznym antykomunizmem nacjonalistycznym", czyli ideologią wrogą nie tylko wobec komunizmu, ale i wobec liberalizmu. Ideologia ta zrodziła się w obrębie pierwszej emigracji porewolucyjnej. Jej recepcja na gruncie rodzimym miała miejsce w publicystyce Aleksandra Sołżenicyna ${ }^{43}$, Igora Szafariewicza ${ }^{44}$, Dmitrija Dudki ${ }^{45}$ i innych (po

${ }^{43}$ Aleksandr Isajewicz Sołżenicyn (1918-2008), wybitny pisarz rosyjski, dysydent, laureat Nagrody Nobla (1970), autor legendarnego Archipelagu GUłag. Mocno związany z rosyjską myślą prawosławną z biegiem lat zbliżał się ku ideom słowianofilskim i panslawistycznym, zabarwionym poglądami nacjonalistycznymi i autorytarnymi [przyp. tłum.].

${ }^{44}$ Igor Rostisławowicz Szafariewicz (1923-2017), wybitny rosyjski matematyk, od lat 60. XX wieku czynnie zaangażowany w ruch obrony praw człowieka i Rosyjskiej Cerkwi Prawosławnej. Później odszedł od idei Andrieja Sacharowa, zblizając się do poglądów Aleksandra Sołżenicyna. Krytykował komunizm z pozycji narodowych (nacjonalistycznych), posługując się także retoryką antysemicką. Z powodu eseju Rusofobia (1982), w którym Szafariewicz pisał o "małym narodzie" (Żydach), którego podstępne działania opanowały "wielki naród” (Rosję), i w efekcie doprowadziły do „rytualnego morderstwa” rodziny carskiej, Szafariewicz znalazł się w ogniu krytyki ponad 400 matematyków z całego świata, członków amerykańskiej National Academy of Sciences. Poglądów swoich jednak nie zmienił [przyp. tłum.].

45 Dmitrij Siergiejewicz Dudko (1922-2004), protojerej Rosyjskiej Cerkwi Prawosławnej, teolog, pisarz, poeta. Wielokrotnie więziony przez władzę radziecką, był popularnym duchownym wśród znacznej części inteligencji, autorem licznych publikacji, organizatorem spotkań religijnych [przyp. tłum.]. 
raz pierwszy w sposób obszerniejszy w zbiorze Spod głazów ${ }^{46}$, w którym publikowali dwaj pierwsi tu wymienieni autorzy). Prawosławie zbudowało jej konieczny komponent: "bezbożnik" nie może być pełnym antykomunistą w rozumieniu tej ideologii.

W świadomości wielu rozpolitykowanych prawosławnych młodszego pokolenia ten nacjonalistyczny antykomunizm stał się prawie kanonicznym autorytetem. W 1986 roku autor jednej odpowiedzi na samizdatową ankietę na temat współczesnego prawosławia radził wątpiącym „częściej czytać znakomitego Wykształciucha [Образованщина] Sołżenicyna, a jeszcze lepiej - nauczyć się go na pamięć" ${ }^{147}$.

Aniszczenko wychodzi z oczywistego dla niego "faktu, że równolegle z duchową eksterminacją narodu rosyjskiego postępował inny proces: kształtowania się rusofobii”. "Nie będę — mówi — zatrzymywał się na analizie rusofobii, została ona pokazana w pracach Aleksandra Sołżenicyna Nasi pluraliści i Igora Szafariewicza Rusofobia. Dodam tylko, że Aksiuczyc w artykule Z głębokości bardzo dokładnie pokazał organiczny związek komunizmofilii z rusofobią".

Tak więc, ci zwolennicy ideologii nacjonalistycznego antykomunizmu, dla których osobista więź z Rosyjską Cerkwią Prawosławną jest najważniejsza (wśród nich wydawcy pisma rosyjskiej kultury chrześcijańskiej "Wybor”, Wiktor Aksiuczyc i Gleb Aniszczenko), wychodzą w swoich ocenach "nowego patriotyzmu" z szeregu politycznych i historiozoficznych twierdzeń, których prawdziwości sami, najwyraźniej, nie sprawdzili. Twierdzenia te przyjęli na wi arę i, w konsekwencji, już teraz uważają je za część ro syjskiej kultury chrześcijańskiej.

2. Światopogląd chrześcijańskich krytyków agresywnego nacjonalizmu ma wiele wspólnego z ideologią, będącą obiektem ich krytyki. Aniszczenko pisze: „Jeśli wspólnota, pozbawiona religijnych podstaw, zamienia się w stado, to $w$ ten sam sposób 'odpowiedź świata', oderwana od prawosławnych korzeni, stwarza przesłanki dla komunistycznego 'internacjonalizmu' i kosmopolityzmu. Proces kastracji rosyjskiej świadomości narodowej trwa od lat siedemdziesięciu"478. Taki, uważa Aniszczenko, powinien być punkt widzenia prawdziwego chrześcijanina, któremu rosyjska kultura jest droga tylko dlatego, że jest ona, w rozumieniu tego autora, „zbudowana na wyższej prawdzie - chrześcijańskich ideałach”.

46 Из-под глыб, ҮMCA-Press, Париж 1974. w zbiorze znalazły się artykuły m.in. A. Sołżenicyna, I. Szafariewicza, M. Poliwanowa, E. Barabanowa. Książka spotkała się z ostrą krytyką oficjalnej propagandy radzieckiej. [przyp. tłum.]

47 «Вестник Русского Христианского Движения» [Париж] 1987, nr 149.

48 Г. Анищенко, Кто виноват?... 
Aniszczenko zaznacza: „[Front] 'Pamięć' postawił kwestię niszczenia rosyjskiej kultury dostatecznie radykalnie i prawdziwie ${ }^{\prime \prime 49}$.

Taką zaś ocenę "nowego patriotyzmu" daje Wiktor Aksiuczyc: „[...] cieszy mnie, że w 'Pamięci' po raz pierwszy głośno powiedziano o licznych, żywotnych naszych problemach. [...] Sądzę, że w określonych kręgach inteligencji stołecznej panują mocno przesadzone poglądy na temat niebezpieczeństw, pochodzących z ruchu 'Pamięci"'50. Aksiuczyc zarzuca autorom apelu "Pamięci" z 8 grudnia 1987 roku, że "nie chcą wyciągnąć wniosków z przesłanek, jakie formułują"51.

*

Tak więc "Pamięć" i jej prawosławnych krytyków jednoczy miłość do kultury rosyjskiej i chęć „przywrócenia tożsamości narodowej". Gleb Aniszczenko i Wiktor Aksiuczyc zarzucają ideologom "Pamięci" niedostateczny antykomunizm i błędne rozumienie chrześcijaństwa. Aniszczenko wyjaśnia: „Historia pokazała, że kultury narodu nie zbawią odrestaurowane świątynie, mogą jej nawet nie zbawić i te, w których odprawia się nabożeństwa. Tożsamość narodu zależy od tego ducha, jaki panuje w świątyni. Jedyne antypody obecnej ideologii to chrześcijaństwo. Gdyby udało się wyjąć z kultury rosyjskiej filar chrześcijaństwa, wówczas przestałaby ona wchodzić w bezpośredni konflikt z ideałami komunizmu"52.

*

Wszystko to przypomina mi epizod z historii chrześcijańskiej apologetyki, mało znanej czytelnikowi rosyjskiemu. W październiku 1930 roku Alfred Rosenberg opublikował antychrześcijańską, antyliberalną i antyżydowską książkę Der Mythus des 20.Jahrhunderts $^{53}$. W styczniu 1934 roku Adolf Hitler mianował Rosenberga swoim pełnomocnikiem do spraw ideologicznych w NSDAP. Z osobistej wypowiedzi Mit XX wieku przekształcił się w oficjalną

49 Tamże.

50 В. Аксючиц, Русский маятник. От коммунистического тупика через либеральный обвал. Заметки очевидиа, Директ-Медиа, Москва-Берлин 2017, s. 137.

51 Tamże, s. 141

52 Г. Анищенко, Кто виноват?.. .

53 Alfred Rosenberg (1893-1946), jeden z najbardziej wpływowych ideologów III Rzeszy, twórca teorii rasistowskiej, którą zawarł w książce Mit XX wieku. Niektórzy uważają go za twórcę sformułowania „ostateczne rozwiązanie kwestii żydowskiej" (Endlösung der Judenfrage) [przyp. tłum.]. 
niemalże wykładnię nazistowskiej ideologii. I wtedy teologowie Niemieckiego Kościoła Ewangelickiego (luterańskiego) poczuli się zobowiązani do udzielenia odpowiedzi na Mit Rosenberga. Tak ukazały się książki Waltera Künnetha Antwort auf den Mythus. Die Entscheidung zwischen dem nordischen Mythus und dem biblischen Christus, Rudolfa Homanna Der Mythos und das Evangelium, Heinricha Hüffmeiera Evangelische Antwort auf Rosenbergs Mythus des 20. Jahrhunderts i innych ${ }^{54}$. Dlaczego o nich wspominam? Dzisiejszy czytelnik tych krytycznych wobec nazistowskiej mitologii dzieł, napisanych w połowie lat trzydziestych XX wieku, również zauważy przede wszystkim punkty wspó In e stanowisk teologów ewangelickich i krytykowanego przez nich Rosenberga. Künneth twierdzi zatem, że chrześcijanin niemieckie narodowe i rasowe wartości rozumie głę b i e j niż Rosenberg; tylko chrześcijańskie Objawienie pozwala poznać Rasę, Naród i Państwo jako porządki stworzonego bytu, zakorzenione w ochraniającej woli Boga. Według Mitu XX wieku, rasa nordycka [германская раса] odwiecznie występuje przeciwko niszczącemu wpływowi żydowskiej „przeciw-rasy". Odrzucając z pozycji chrześcijańskich rasistowskie poglądy Rosenberga na temat Starego Testamentu, Künneth dodaje, że szkodliwość współczesnego "światowego żydostwa” jest konsekwencją klątwy, ciążącej na Żydach z powodu ukrzyżowania Chrystusa. Rosenberg natomiast, odrzucając chrześcijaństwo, nie jest w stanie zrozumieć - opisanego przez siebie - tego najgłębszego źródła nienawiści rasowej.

W połowie lat trzydziestych XX wieku niemieccy teolodzy jeszcze nie rozumieli, że narodowy socjalizm jest ideologią totalną (w wyjaśnionym wyżej znaczeniu tego słowa) i dlatego $\mathrm{n}$ i e $\mathrm{n}$ a leży korzystać z jej języka. Możnaw nim wyrazić tylko znaczenia do niej należące. To niezrozumienie jest możliwe do wyjaśnienia na gruncie historyczno-kulturowym: wspomniane początkowe podobieństwo stanowisk (a dokładniej, podobieństwo szeregu zarzutów dotyczących wiary) nie pozwoliło chrześcijańskim oponentom Rosenberga znaleźć punktu widzenia niezbędnego do konsekwentnej i głębokiej krytyki narodowego socjalizmu. Taki punkt widzenia powinien być przeciwstawny obiektowi krytyki, tj. znajdować się jeśli nie "na górze”, to przy-

54 Walter Künneth (1901-1997), wybitny teolog ewangelicki, w czasie II wojny światowej krytykował antysemityzm nazistowski z pozycji antysemityzmu chrześcijańskiego. Oponent Rudolfa Karla Bultmanna, zwolennika demitologizacji przekazu Nowego Testamentu. Główne dzieło Künnetha to Theologie der Auferstehung (1933). Rudolf Homann (1894-1973), teolog luterański, pastor w Dortmundzie, Düsseldorfie i Münsterze. Heinrich Hüffmeier (1901-1956), pastor w Wilmersdorfie, dzielnicy od 1920 w obrębie Wielkiego Berlina [przyp. tłum.]. 
najmniej gdzieś „z boku”. A ewangeliccy chrześcijanie czuli się wówczas we wnątrz burzliwie rozwijającego się życia narodowego.

Okazuje się, że ówczesne (pierwszej połowy lat 30. XX wieku) niezrozumienie tego, że kościół chrześcijański nie może flirtować z „ideą narodową”, historycznie jest zrozumiałe. Jak pisał Karl Barth, największy teolog protestancki naszego wieku i konsekwentny wróg nazizmu, „w Niemczech istniało wiele powodów, by opowiedzieć się właśnie za tą nową kombinacją (chrześcijaństwa z ideą narodową - S. L.). Była ona szczególnie korzystna dla niemieckiego luteranizmu [...]. Mogłaby stać się potężnym strumieniem, w którym zjednoczą się wciąż jeszcze oddzielone nurty historii niemieckiego kościoła [...]. Wydawało się, że podniesie wyrzucony na brzeg statek kościoła i, jak fala przypływowa, w końcu wyniesie go na otwarte morze narodowego życia".

To złudzenie jest tak samo oczywiste, jak oczywista jest przeanalizowana przez nas nieudana próby Bierdiajewa przeciwstawienia się rasistowskiemu antysemityzmowi przy użyciu tradycyjnego chrześcijańskiego wizerunku judaizmu i Żydów.

Ale przecież katastrofy naszego stulecia właśnie ujawniły niezgodność tych poglądów i ideologii, które wcześniej wydawały się skojarzone ze sobą (odnosi się to na przykład do „związku” liberalnej tradycji z nacjonalizmem: na takim połączeniu ufundowanych było wiele nauk politycznych XIX wieku). W świecie idei zaistniał wielki podział. Oczywistymi prawdami stały się myśli, które wcześniej były sądami nieznaczącej mniejszości. I odwrotnie, niemożliwe stało się powtórzenie tego, co wcześniej postrzegano jako miejsce wspólne.

Katolicki teolog Johann Baptist Metz pisze: „Daję moim studentom pozornie proste, ale bardzo trudne kryterium oceny systemów teologicznych. Zapytajcie samych siebie: czy teologia, której się uczycie, mogłaby być taka sama przed i po Auschwitz. Jeśli mogłaby, to trzymajcie się od niej jak najdalej!"

O be c n i e tego rodzaju wątpliwości są niewybaczalne.

\section{III}

Jednak to oddzielenie, wyjaśnienie i oczyszczenie nie miało na nas wpływu. Właśnie dlatego najnowsze prawosławne odpowiedzi na nienawistny mit rosyjskiego nacjonalizmu ujawniają b r a k p u n k t u w id ze n ia, który byłby adekwatny dla tej krytycznej 
analizy. Prawosławna krytyka nie może obejmować całego tematu, brakuje jej głębi: w końcu, jak już widzieliśmy, nie ma własnej pozycji semantycznej. w naszym przypadku oznacza to, że nie ma ona niezależnie wypracowanego rozumienia chrześcijaństwa; rozumienia obejmującego doświadczenie naszej katastrofy historycznej; rozumienia, które zrodziło się z myśli o tym, dlaczego w roku 1917 "nie uratowały nas te świątynie, w których odbywały się nabożeństwa", tj. dlaczego rosyjskie prawosławie okazało się nie do utrzymania w obliczu bolszewizmu, dlaczego Rosyjska Cerkiew Prawosławna nie poradziła sobie ze sprawą duchowego przywództwa ludu.

Bieda nie w tym, że autorzy analizowanych prac, podobnie jak wielu innych współczesnych pisarzy prawosławnych, nie mogą i nie chcą oddzielić tego, co "chrześcijańskie" od tego, co "narodowe"; nie tylko w tym, że, jak się wydaje, uważają za klasykę współczesnej myśli chrześcijańskiej Rusofobię Szafariewicza, będącą nową redakcją mitu o wszechświatowym spisku żydowskim i o narodzie rosyjskim jako ofierze tego spisku (jak widzieliśmy, to założycielski mit "nowego patriotyzmu”). Gorsze jest to, że niezmieniona została kulturowa matryca, utwierdzająca podobne przekonania: "obraz naszego chrześcijańskiego bytu” pozostał taki sam ${ }^{55}$.

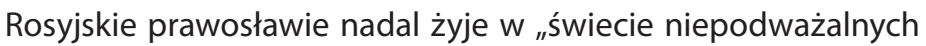
twierdzeń", który runął pod ciosami historii XX wieku. Zadanie oczyszczenia, tj. krytycznej analizy tradycji, wcale nie zostało określone. Przeciwnie, starania zmierzają właśnie do zachowania integralności tradycji prawosławnej, której wszystkie elementy uznawane są za wartościowe i ważne. Dlatego dzisiaj w Rosji odradza się to samo prawosławie, które nie przetrwało próby i pod wieloma względami już pokazało swoją porażkę.

Myślę, że nasze prawosławne chrześcijaństwo utraciło charakter Ewangelii, tj. radosnej wiadomości, "dobrej nowiny". W zamian za to stało się „rdzeniem rosyjskiej kultury”. Tkanina tego naszego prawosławia utkana jest ze splotów różnorakich politycznych, narodowych i duchowych aspiracji. Zaszło coś bardzo prostego: po tym, jak nowe typy samoświadomości (самопонимания), na przykład „internacjonalizm komunistyczny", zaczęły tracić na znaczeniu, odradzały się dawne formy świadomości mas: „religijna” $i$ "narodowa”. Za ideałem nie trzeba było chodzić daleko, był pod ręką i gotowy do użycia. Wszelako stopień bliskości, nieprzenikalności tego ideału (dokładniej: tej

55 F.-W. Marquardt, Christsein nach Auschwitz... 
ideologii) ujawnia się powoli w „żywym doświadczeniu religijnym", o którym u nas zawsze się pisze i mówi z taką słodkością. To, co "religijne" i "narodowe" wewnątrz naszego prawosławia, scaliło się do tego stopnia, że niemożliwe jest "wyodrębnienie fundamentu chrześcijaństwa w czystej postaci" (pamiętamy, cytowane w pierwszej części tego studium, słowa Roberta Erickse$\left.n a^{56}\right)$, i nawet nikt do tego nie dąży.

Naturalnie, t a ki e prawosławie nie daje autentycznego wsparcia sprzeciwowi wobec rasistowskiego antysemityzmu "nowych patriotów". W rzeczywistości, mitotwórczy nacjonalizm głosi: „Syjonizm przeszedł do otwartego ataku na front patriotyczny!" (Apel Frontu Narodowo-Patriotycznego "Pamięć" z dnia 1 lutego 1988 roku). A Gleb Aniszczenko wyjaśnia, że „proponowana przez 'Pamięć' odpowiedź na pytanie 'Kto jest winny?' wcale nie jest fikcją, $\mathrm{u}$ jej podstaw leży o wiele bardziej realna i poważna kwestia: problem dramatycznych (jeśli nie tragicznych) relacji między narodami rosyjskim i żydowskim w rosyjskiej historii i rosyjskim życiu (podkr. - S.L.). Ale ten problem może być pożywką dla wszelkiego rodzaju zjawisk pasożytniczych".

Jakżeż to przypomina odpowiedź luterańskiego teologa Waltera Künnetha na mit o konfrontacji ras — aryjskiej i żydowskiej — „w niemieckiej historii i niemieckim życiu"...

Jeżeli czegokolwiek można oczekiwać od prawosławnych teologów i publicystów w zakresie przeciwstawienia się antysemityzmowi, to wyłącznie powtórzenia tych twierdzeń, z których korzystał również Bierdiajew:

— chrześcijaństwo jest ponadnarodowe i personalistyczne;

- „antysemityzm jest sprzeczny z Ewangelią Chrystusową, która jest skierowana do wszystkich ludzi bez jakiejkolwiek dyskryminacji rasowej" (są to słowa z opublikowanego w kwietniu 1990 roku Oświadczenia rosyjskich teologów prawosławnych za granica z powodu wzrostu antysemityzmu w Rosji);

- apostoł Paweł w Liście do Rzymian przekazał normatywną chrześcijańską interpretację judaizmu, współistniejącego z Kościołem (wybranie Żydów nie zostało zniesione, lecz czasowo zawieszone po to, aby ustąpić miejsca poganom; na końcu czasów "cały Izrael zostanie zbawiony");

56 R. Ericksen, Theologians under Hitler..., s. 46. 
— nie będziemy mówić o winie Żydów za śmierć Zbawiciela, lepiej pomyślmy o tym, że sami go codziennie rozpinamy na krzyżu przez swoje grzechy.

To wszystko, albo prawie wszystko, co mogą powiedzieć prawosławni, zaniepokojeni tym, że "niektóre osoby i ugrupowania łączą antysemityzm z Prawosławiem" (z Oświadczenia rosyjskich teologów prawosławnych). Odnosi się to również do niedawnych polemicznych uwag Zoi Krachmalnikowej wobec Rusofobii Igora Szafariewicza ${ }^{57}$.

Wiemy, że taka teologia pozwoliła Kościołowi (Церкви) milczeć przez wszystkie te lata, kiedy naziści eksterminowali Sześć Milionów.

Milczy Rosyjska Cerkiew Prawosławna i teraz, choć jej zagraniczni członkowie wiedzą: „Jeszcze do dzisiaj wisi nad światem groza Zagłady Żydów w czasie II wojny światowej".

Obawiam się, że nie przerwie ona tego milczenia, ponieważ nie ma nic do powiedzenia w obronie Żydów.

IV, 1988 - IX, 1990

Przełożył Marian Kisiel

57 Zoja Aleksandrowna Krachmalnikowa (1929-2008), radziecka i rosyjska literaturoznawczyni, publicystka prawosławna, dysydentka, obrończyni praw człowieka. Lozow ma na myśli artykuł Krachmalnikowej Русофобия. Антисемитизм. Христианство («Нева» 1990, nr 8, s. 163-178), przedrukowany następnie w tomie: 3. Крахмальникова (red.), Русская идея и евреи. Роковой спор. Христианство, антисемитизм, национализм, Наука, Восточная литература, Москва 1994 [przyp. tłum.]. 